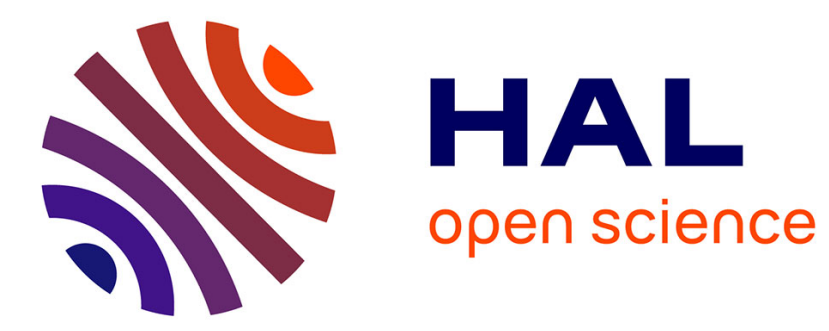

\title{
What's in a name? The three genealogies of the social in social epigenetics
}

Séverine Louvel

\section{To cite this version:}

Séverine Louvel. What's in a name? The three genealogies of the social in social epigenetics. Social Science Information, 2020, pp.053901841989700. 10.1177/0539018419897001 . halshs-02448128

\section{HAL Id: halshs-02448128 \\ https://shs.hal.science/halshs-02448128}

Submitted on 22 Jan 2020

HAL is a multi-disciplinary open access archive for the deposit and dissemination of scientific research documents, whether they are published or not. The documents may come from teaching and research institutions in France or abroad, or from public or private research centers.
L'archive ouverte pluridisciplinaire HAL, est destinée au dépôt et à la diffusion de documents scientifiques de niveau recherche, publiés ou non, émanant des établissements d'enseignement et de recherche français ou étrangers, des laboratoires publics ou privés. 
To cite this article Louvel, S. (2020). What's in a name? The three genealogies of the social in social epigenetics. Social Science Information. https://doi.org/10.1177/0539018419897001

\title{
What's in a name? \\ The three genealogies of the social in social epigenetics
}

\author{
Séverine Louvel \\ Université Grenoble Alpes, CNRS, Sciences Po Grenoble, Pacte, and Institut Universitaire de France \\ severine.louvel@iepg.fr
}

\begin{abstract}
Social epigenetics - the study of the epigenetic mechanisms through which social environments become biologically embodied - epitomizes recent claims that the boundaries between the natural and the social sciences should be reduced. Relying on a bibliometric study and on a qualitative analysis of publications in social epigenetics, this paper investigates how this research area defines and operationalizes the social dimensions that may have an impact on health status and disease risk. The paper also addresses how the social sciences engage with social epigenetics. First, the paper traces social epigenetics back to five epistemic backgrounds - two in animal research (on social defeat and early-life adversity) and three in human studies (on trauma, early-life nutrition and social adversity over the life-course). Second, it outlines the quest for epigenetic markers of social environments, and the associated expectations and controversies. Third, it analyses the three modes of engagement of the social sciences with human studies in social epigenetics: rejection (social epigenetics trapped in the quest for a 'social brain'); warning and call for responsibility (social epigenetics has shifted from socioeconomic contexts to individual behaviors); and support and active contribution (social epigenetics may strengthen social studies of health). This paper argues that recent developments in social epigenetics could strengthen this third mode of engagement and expand the scope of interdisciplinary collaboration between the natural and the social sciences.
\end{abstract}

\section{Keywords}

bibliometric analysis, biology and society, biosocial, interdisciplinarity, social epigenetics, social studies of health

\section{Résumé}

L’épigénétique sociale - l'étude des mécanismes épigénétiques par lesquels les environnements sociaux sont biologiquement incorporés - illustre bien de récentes déclarations demandant à abaisser les barrières entre les sciences naturelles et les sciences sociales. À partir d'une étude bibliométrique et d'une analyse qualitative d'articles en épigénétique sociale, cet article cherche à comprendre comment ce domaine de recherches définit et intègre les dimensions sociales qui peuvent avoir un impact sur l'état de santé et les risques de maladie. L'article étudie aussi comment les sciences sociales se saisissent de l'épigénétique sociale. Tout d'abord, l'article identifie cinq contextes épistémiques dans lesquels s'ancre l'épigénétique sociale - deux dans la recherche animale (sur la défaite sociale et l'adversité en début de vie) et trois dans la recherche sur des sujets humains (sur le traumatisme, l'alimentation infantile et l'adversité sociale au cours de la vie). Dans un deuxième temps, il brosse le tableau de la recherche de marqueurs épigénétiques des environnements sociaux, et les attentes et controverses qui y sont associées. Enfin, il analyse les trois modes d'engagement des sciences sociales avec la recherche conduite chez l'humain en épigénétique sociale : le rejet (l'épigénétique sociale serait enfermée dans la quête d'un 'cerveau social') ; la mise en garde et l'appel à la responsabilisation (l'épigénétique sociale se serait déplacée des contextes socio-économiques aux comportements individuels); et l'appui et la contribution active (l'épigénétique sociale pourrait étayer les études en sociologie de la santé). Cet article avance l'idée que les développements récents en épigénétique sociale pourraient renforcer ce troisième mode d'engagement et étendre le périmètre de la collaboration interdisciplinaire entre sciences du vivant et sciences sociales. 
To cite this article Louvel, S. (2020). What's in a name? The three genealogies of the social in social epigenetics. Social Science Information. https://doi.org/10.1177/0539018419897001

\section{Mots-clés}

analyse bibliométrique, biologie et société, biosocial, épigénétique sociale, interdisciplinarité, sociologie de la santé

\section{Introduction}

There is a growing body of social science literature claiming that the boundaries between the social and the natural sciences should be reduced (Callard \& Fitzgerald, 2015; Meloni et al., 2018). Central to this literature is the argument that the biological, cultural and social dimensions of human behavior cannot easily be separated and that researchers from all disciplines should work to move past the century-old division between nature and nurture (Lock \& Palsson, 2016). This perspective is not new in itself but relies on emerging scientific evidence from areas of the biological sciences such as the neurosciences, research on the microbiome, and post-genomic research - among which environmental epigenetics appears prominently (Richardson \& Stevens, 2015). Epigenetic modifications are chemical markers which are either attached to a DNA sequence or which modify the chromatin structure (a complex of proteins and DNA found inside the nucleus of eukaryotic cells). These modifications act on gene expression levels and therefore influence a person's health status and risk of disease. In the early 2000s, research in epigenetics shifted from focusing on a purely biological science to being a research field which could appeal to the human and social sciences (Landecker \& Panofsky, 2013). In particular, environmental epigenetics brought increasing scientific evidence - first in animal models, later in human cohorts - that a variety of material and social environments (such as nutrition, stress, lifestyle, exposure to pollutants etc.) were temporarily or permanently associated with epigenetic modifications. Furthermore, from the mid-2000s onwards, researchers began to claim that some of these modifications could be transmitted from one generation to the next or even trans-generationally.

Among the various research areas covered by environmental epigenetics, social epigenetics is more specifically presented as a promising interdisciplinary crossroad between the biological and the social sciences. It designates 'the study of how social experiences affect genes and our biology. Our experiences do not alter the genetic code itself; however, social experiences may bring about changes in the various molecules that interact with DNA, determining which genes are switched on or off. Recent studies suggest that social stressors may affect health status through epigenomic modifications of various biological pathways.' ${ }^{1}$ Social epigenetics leads to high epistemological and practical expectations. At the epistemological level, it is considered to be a paradigmatic shift from genecentered biology loaded with considerable biological determinism (Landecker \& Panofsky, 2013). As the epigenome is 'plastic' and 'reactive' to all kinds of social environments (Lappé \& Landecker, 2015), 'sociological-cum-biological research programs' seem to open up (Meloni, 2013). At the practical level, social epigenetics could bring a new understanding of social inequalities in health and thus have major health policy implications (Claeys \& Vialatte, 2016). In particular, it could change the dominant approaches to the prevention of chronic diseases such as diabetes, cardiovascular and neurodegenerative diseases - for instance, by considering them to be developmental diseases caused by social position early in life, rather than by adult life-style.

Despite growing scientific interest and media attention to social epigenetics, there is to date limited social science inquiry into which sorts of 'social experiments' and 'social stressors' are of interest to social epigenetics. However, research into the broader area of environmental epigenetics encompassing material, physical and social environments - has stressed that it may not live up to expectations. Anthropologists and sociologists have detected evidence of 'reductionism' - that is, deletion of complexity - in how environmental epigenetics conceptualizes and operationalizes material and physical 'environments' (Lock, 2015; Niewöhner, 2011). Critical social science research has mostly focused on highly-cited studies, for instance the study by Weaver et al. (2004) on the epigenetic 'programming' of maternal behavior (Kenney \& Müller, 2017).

\footnotetext{
${ }^{1}$ Source: National Institutes of Health, https://www.nih.gov/news-events/news-releases/nih-establishes-newresearch-social-epigenomics-address-health-disparities
} 
To cite this article Louvel, S. (2020). What's in a name? The three genealogies of the social in social epigenetics. Social Science Information. https://doi.org/10.1177/0539018419897001

The present paper follows this thread of analysis by exploring how social epigenetics selects the relevant 'social environments' and which biosocial 'intertwinements' it favors. It contributes to the social science literature in three ways. First, it focuses on social epigenetics - e.g. on studies which explicitly address epigenetic modifications caused by 'social experiences' - and lays out its representations of the social world. Second, it goes beyond presumably exemplary research to investigate the internal heterogeneity of social epigenetics and the possible tensions between its research agendas. Third, it exposes the different positions of the social sciences on human studies in social epigenetics and it characterizes the relationships between the natural and the social sciences. For that purpose, this article draws on a bibliometric analysis of scientific articles published in the area of social epigenetics as well as on a qualitative analysis of 25 journal articles.

I will now recall why environmental epigenetics in general, and social epigenetics in particular, has aroused high expectations among social scientists, while being at the same time a matter of concern for rendering social forces and structures invisible. I will then present descriptive statistics of articles published in social epigenetics to gain a comprehensive view of the area. Next, I will use a combination of network and qualitative analysis to characterize the five knowledge communities from which social epigenetics derives its main characterizations of the social. For each community, I lay out the search for epigenetic markers of social environments, along with the associated expectations and controversies. I will also argue that human studies in social epigenetics eventually put forward three definitions of social environments - childhood trauma, early-life nutrition, and social adversity over the life-course - which lay the groundwork for three different engagements of the social sciences with social epigenetics: rejection; warning and call for responsibility; and support and active contribution. I conclude the paper by suggesting that recent research avenues in social epigenetics might strengthen this third mode of engagement.

\section{The social science perspective on environmental and social epigenetics: expectations and concerns}

Environmental epigenetics, along with other fast-growing areas of research in the life sciences, has inspired the hope that the social sciences can collaborate with the biological sciences without the latter taking over - as occurred during an unfortunate sociobiology episode in the 1970s (Meloni, 2013). Indeed, epigenetics would not favor 'biologism' - that is, it would not lend weight to the idea that social behaviors are biologically determined. On the contrary, environmental epigenetics would address how material, social and cultural contexts become biological, and how this biological embodiment has an enduring influence on social experiences and positions: 'While the importation of biological knowledge into the human/social sciences often contributes to reinforce the foundational view of biology as what always comes first in the chain of causal factors (which is the essence of biologism), an increasing body of research within the life sciences is leaving behind all this metaphorical apparatus [...] A social-cum-biological exploration is made even more plausible by this postgenomic approach, but losing the allure and authoritative dimension that is often attributed to the importing of biological knowledge into the social.' (Meloni, 2013: 12)

Expectations have been particularly high regarding social epigenetics. Social epigenetics is sometimes conflated with environmental epigenetics: 'Social epigenetics is the study of the molecular mechanisms by which early-life experiences influence gene expression and have persistent effects on human physiology and health' (Park \& Kobor, 2015); 'the idea that pollution, parenting, stress, adversity or poverty shape the human body and brain such that it is more vulnerable to illness or unrealized potential' (Landecker, 2016). However, the expression has also been coined to designate an area of environmental epigenetics which specifically investigates the epigenetic modifications caused by social environments: 'scientific research in the field of social epigenetics has shed light on molecular mechanisms, such as DNA methylation, through which living conditions and social structures can impact gene expression and confer different biological vulnerability to specific diseases to some 'social groups' (Saulnier \& Dupras, 2017); [social epigenetics studies] 'associations between 
To cite this article Louvel, S. (2020). What's in a name? The three genealogies of the social in social epigenetics. Social Science Information. https://doi.org/10.1177/0539018419897001

socioeconomic status and epigenetic markers that predict vulnerability to diseases' (Loi, Del Savio \& Stupka, 2013).

Several social scientists have suggested that, so far, research in environmental and social epigenetics does not live up to expectations. With few exceptions, this critical social science research relies on the study of seminal research. Two authors have conducted first-hand studies of this seminal research - observations and interviews (Niewöhner, 2011; Lloyd \& Raikhel, 2018), while others have studied environmental and social epigenetics through highly-cited articles. As for environmental epigenetics, Landecker has examined the seminal study by Waterland and Jirtle (Waterland \& Jirtle, 2004) on the link between nutrition and the intergenerational epigenetic transmission of disease risk (Landecker, 2011). Social science inquiries of social epigenetics have used a range of methods and approaches. Niewöhner (Niewöhner, 2011) has produced an ethnographic analysis of the Weaver et al. research on how poor maternal care epigenetically programs rat pups to stress (Weaver et al., 2004), while Richardson (Richardson, 2015), Kenney and Müller (Kenney and Müller, 2017) have described the narratives about motherhood that appear in this study as well as others. Lloyd and Raikhel (Lloyd \& Raikhel, 2018) draw on interactions with members of the McGill Group for Suicide Studies to analyze the 'style of reasoning' emerging with the McGowan et al. study on how childhood trauma increases the risk of suicide later in life (McGowan et al., 2009). Landecker and Panofsky (Landecker \& Panofsky, 2013) and Chiapperino and Testa (Chiapperino \& Testa, 2016) analyze the potential applications to social policy of the study by McGuiness et al. on the association between childhood low socioeconomic status and DNA methylation at adult age (McGuinness et al., 2012). Lastly, Meloni (Meloni, 2017) also discusses the implications for public policy of the rethinking of race in epigenetic - rather than genetic - terms, as laid out in studies on the biological 'embodiment' of racism - how it affects bodies and increases disease risk - through epigenetic mechanisms by Jasienska, and Kusawa and Sweet (Jasienska, 2009; Kuzawa \& Sweet, 2009).

Therefore, these social science scholars have selected a small set of studies which they view as paradigmatic for environmental and social epigenetics - even though they are well aware of potential scientific flaws and even controversies²:

'If there is one experiment that has become paradigmatic for the science of epigenetic maternal effects, it is the experiment on 'epigenetic programming by maternal behavior' (Weaver et al, 2004)’ (Kenney \& Müller, 2017).

'My point of entry to look at the present postgenomic remaking of race via epigenetics are two articles that, though speculative, may be seen as exemplar (in Kuhn's sense) of the new way of framing racial disparities in health' (Meloni, 2017).

This social science research argues that environmental and social epigenetics mostly relies on laboratory experiments on animal models, for which social environments are reduced to a few controlled stress experiments such as parental separation and dietary deprivation (Chung et al., 2016). But even epigenetic research on human cohorts can imply the 'molecularization of biography and milieu' (Niewöhner, 2011). It selects a few experiences or events and transforms them from sociallyand culturally-embedded practices to 'environmental exposures' or individual 'risk factors' whose biological consequences can be measured.

Critical social scientists argue that deleting the complexity of 'social environments' has sociopolitical implications. Indeed, it renders social forces, positions and structures invisible: 'Although involved epigeneticists acknowledge in principle social, economic, and political variables

\footnotetext{
2 Meloni (2017) acknowledges that the grounds for Jasienska's article are 'problematic' (2017: 6) but he chooses to leave aside 'the scientific plausibility of these claims' (2017: 7). Similarly, Chiapperoni and Testa (2016) mention that 'the study uses an admittedly still coarse inroad into the epigenome (global values of DNA methylation yet to be resolved into the more digitally actionable, sequencing-based knowledge of epigenetic differences and dysfunctions)'. However, they 'include it here as a salient example of the edge towards which epigenetic evidence is being integrated within 'classically' defined societal preoccupations' (2016: 213). As I have argued elsewhere, social scientists tend to exemplify social epigenetics from papers which are either controversial or fail to provide evidence that social environments are embodied through epigenetic mechanisms (Louvel, 2018).
} 
To cite this article Louvel, S. (2020). What's in a name? The three genealogies of the social in social epigenetics. Social Science Information. https://doi.org/10.1177/0539018419897001

that contribute to the unequal distribution of health and illness, many, but not all, essentially set these variables to one side in order to conduct, standardize, and regulate their laboratory work. Hence, the consolidation of a newly assembled neoreductionistic approach to the human body is in the making' (Lock, 2015). Epigenetics, as other post-genomic sciences, could thus favor 'a reductionist regime of perceptibility in which social structure and social processes, especially, tend to disappear' (Shostak \& Moinester, 2015). The emphasis on lifestyle and individual behaviors could favor both the 'micromanagement of the individual body (e.g. through health advice and clinical practice) [and] the macrosurveillance of the body politics (e.g. through public health interventions)' (Saldaña-Tejeda, 2018). It may also give strength to the vision of health risk as racialized and gendered (Mansfield, 2012). Research on maternal care and nutrition tends to reinforce 'preheld ideas about the role of mothers in the psychological and physical health of their offspring' (Kenney \& Müller, 2017) and to reduce pregnant mothers to 'epigenetic vectors' of disease risks who should therefore be closely monitored (Richardson, 2015). Lastly, recent social science investigations show that the 'molecularization' of environments at work in epigenetic research labs is expanding in new directions. In particular, while research in epigenetics still tends to overstudy maternal transmissions (Sharp, Lawlor \& Richardson, 2018), there is now a significant interest in the father's influence. However, as this research reduces paternal influence to 'father-as-sperm influence' - i.e. epigenetic transmission through the paternal germline - it might reinforce stereotypical gender roles in parenting (Chiapperino \& Panese, 2018).

Critical examination of seminal research in environmental and social epigenetics therefore suggests that it may do little to bridge the divide between nature and nurture, or between the biological and the social sciences. Social epigenetics is a fast-growing area of research with dedicated funding programs, research centers, scientific journals and conferences. There is a need to look beyond exemplary or paradigmatic research to address more broadly which scientific communities are involved, how they define social environments, and how they lay the groundwork for criticism from or dialogue with the social sciences. For that purpose, I have conducted a bibliometric analysis of scientific publications in social epigenetics retrieved from the Web of Science (WOS), as well as a qualitative content analysis of 25 scientific articles contained in my database.

\section{An overview of publications in social epigenetics}

Bibliometrics - broadly defined as the statistical analysis of scientific literature - brings valuable insights on the development of research areas bridging several scientific communities. It has recently been applied to studies of the emergence of synthetic biology (Raimbault, Cointet \& Joly, 2016) and global health (Weisz, Cambrosio \& Cointet, 2017). Indeed, it enables one to trace the social organization of emerging fields (e.g. main authors, institutions, funding sources, research networks, and journals) as well as their cognitive structures (e.g. main objects, concepts or methods). In this paper, I use bibliometrics in two ways: first, to get a comprehensive view of the recent rise of social epigenetics (descriptive statistics); then, to characterize its epistemic dimensions, in particular which distinct research domains it draws from.

I give detailed information on my bibliometric analysis in the annex of this paper (see Table 3). I built a corpus of 1,933 scientific articles from the Web of Science Core Collection, published in English between 2000 and 2018. ${ }^{3}$ Social epigenetics expanded more than a decade after general epigenetics, and is still very small by comparison. Interest in social epigenetics really developed in the 2010s, with the annual number of publications steadily increasing from 73 in 2010 to 299 in 2018. This area still attracts many scientists, as indicated by the high and rather stable ratio of newcomers among authors (Figure 1). The Web of Science Core Collection covers more than 20,000 scientific journals:
https://clarivate.com/products/web-of-science/web-science-form/web-science-core-collection/ 
To cite this article Louvel, S. (2020). What's in a name? The three genealogies of the social in social epigenetics. Social Science Information. https://doi.org/10.1177/0539018419897001

Figure 1 . The rise of social epigenetics in the early $2010 \mathrm{~s}$

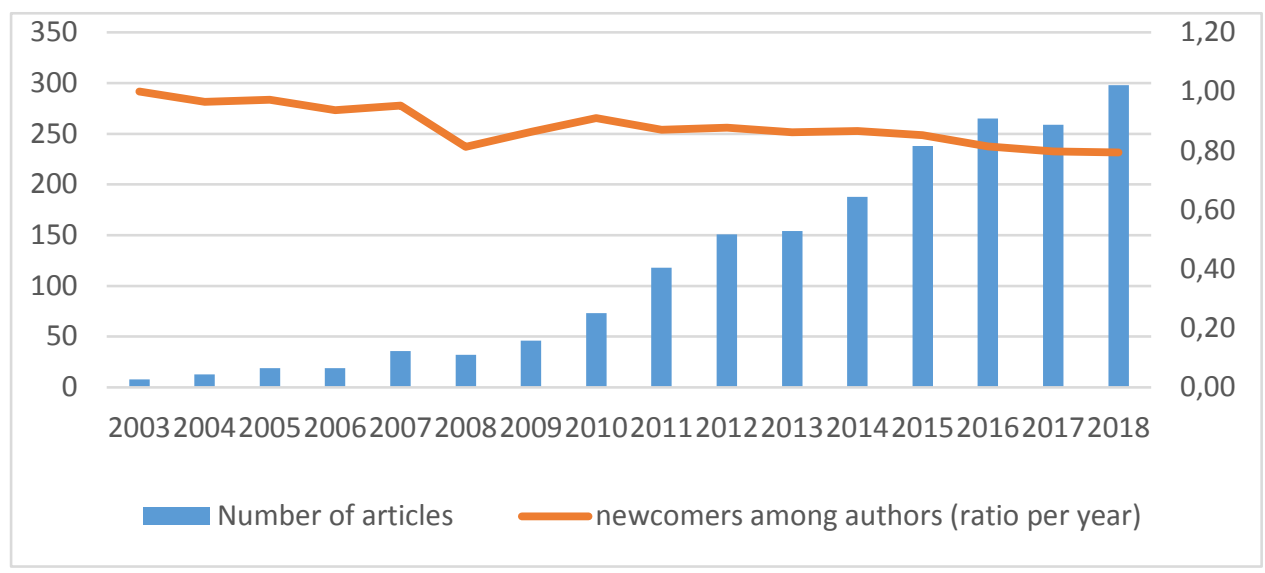

The first papers in social epigenetics were published in the early 2000s in neuroscience, psychiatry, and behavioral sciences. But social epigenetics really took off when researchers from these domains began to collaborate with biochemists and molecular biologists to find the molecular bases for the influence of the environment on behavior. In particular, they started looking at epigenetic modifications - changes in DNA methylation and chromatin structure - which were studied since the 1980s and 1990s in developmental biology and cancer biology. The delayed rise of social epigenetics is attributed to the initial resistance of neuro- and behavioral scientists (who looked to neural connections rather than gene regulation to uncover the biological mechanisms underlying behavior), as well as the initial resistance of cancer and molecular biologists (who predominantly thought epigenetic mechanisms were important for embryonic or cancer cell development but less important throughout life) (Buchen, 2010).

Today, social epigenetics continues to be anchored in neuroscience and in psychiatry, with about one third of articles published in journals classified under these two Web of Science categories (Figure 2). The impact factors of these journals - a measure that indicates their recognition in a given research area - are largely in the top $25 \%$ of their subject category (Table 1 ). The remaining $65 \%$ of the articles are published in a wide range of journal categories, including genetics (7.3\%), behavioral science (7.2\%), biochemistry/molecular biology (6.5\%), endocrinology/metabolism (6.3\%), pharmacology/pharmacy (6.2\%), public/environmental/occupational health (5.3\%), and social science (5.2\%) (Figure 2 and Table 2). 
To cite this article Louvel, S. (2020). What's in a name? The three genealogies of the social in social epigenetics. Social Science Information. https://doi.org/10.1177/0539018419897001

Figure 2. Evolution since the 2000s of the top $10 \mathrm{Web}$ of Science categories for social epigenetics articles

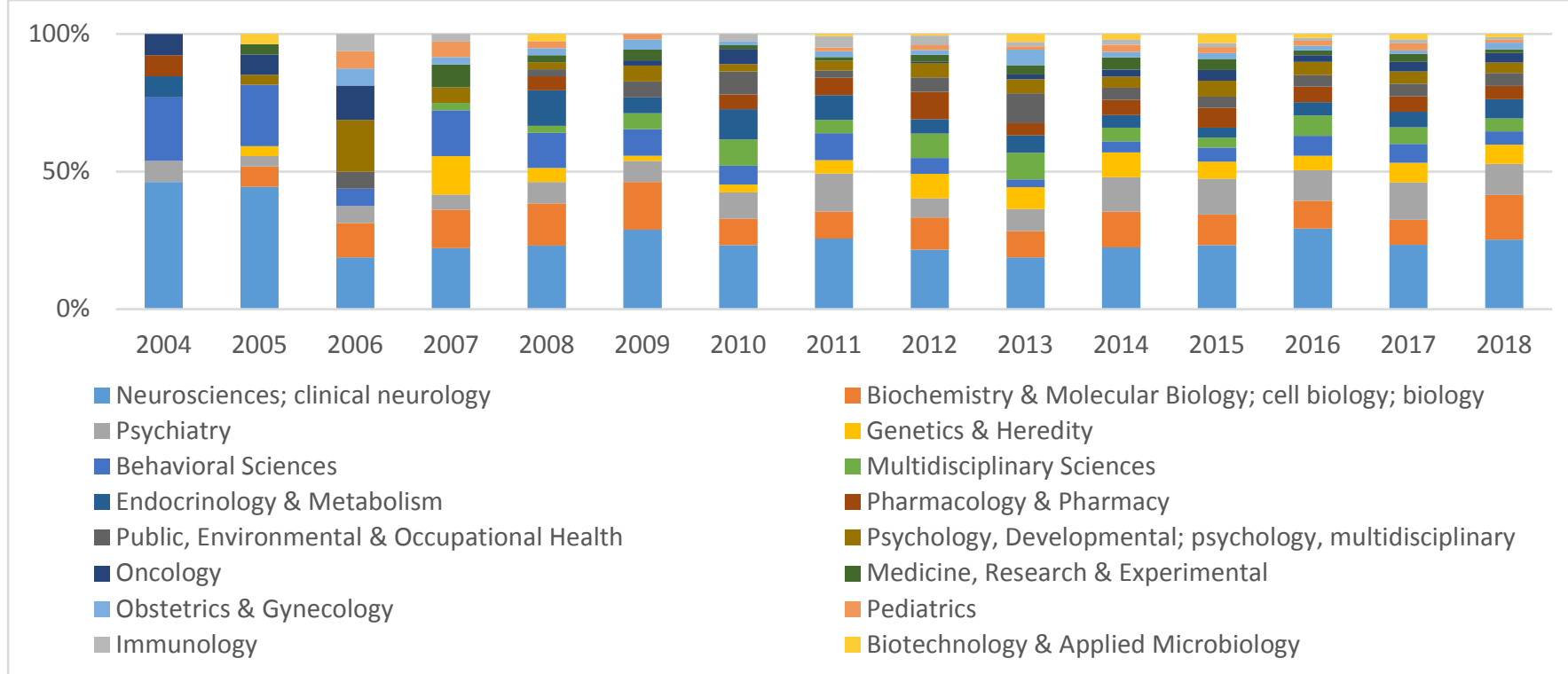

Table 1. Journal impact factors (IF) of journals that have published more than 15 articles in social epigenetics

\begin{tabular}{|l|r|l|l|l|l|}
\hline & $\begin{array}{l}\text { Number } \\
\text { of articles } \\
\text { published }\end{array}$ & $\begin{array}{l}\text { Subject category } \\
(1)\end{array}$ & $\begin{array}{l}\text { Journal IF - } \\
\text { Subject } \\
\text { quartile } \\
\text { category }\end{array}$ & $\begin{array}{l}\text { Subject } \\
\text { category (2) }\end{array}$ & $\begin{array}{l}\text { IF - } \\
\text { subject } \\
\text { quartile } \\
\text { category }\end{array}$ \\
\hline Plos One & 51 & & & & \\
\hline $\begin{array}{l}\text { Neuroscience and } \\
\text { Biobehavioral Reviews }\end{array}$ & 24 & Neurosciences & Q1 & $\begin{array}{l}\text { Behavioral } \\
\text { sciences }\end{array}$ & Q1 \\
\hline $\begin{array}{l}\text { Proceedings of the } \\
\text { National Academy of } \\
\text { Sciences of the United } \\
\text { States of America }\end{array}$ & 23 & & & & \\
\hline Psychoneuroendocrinology & 23 & Neurosciences & Q1 & Psychiatry & Q1 \\
\hline Journal of Neuroscience & 19 & Neurosciences & Q1 & & \\
\hline Neuroscience & 18 & Neurosciences & Q2 & & \\
\hline $\begin{array}{l}\text { Development and } \\
\text { Psychopathology }\end{array}$ & 17 & $\begin{array}{l}\text { Psychology, } \\
\text { developmental }\end{array}$ & Q1 & & \\
\hline Scientific Reports & 17 & & & & \\
\hline Translational Psychiatry & 17 & Psychiatry & Q1 & & Q1 \\
\hline Biological Psychiatry & 15 & Neurosciences & Q1 & Psychiatry & \\
\hline Epigenetics & 15 & & & & Endocrinology \\
\hline \& metabolism & Q1 \\
\hline
\end{tabular}


To cite this article Louvel, S. (2020). What's in a name? The three genealogies of the social in social epigenetics. Social Science Information. https://doi.org/10.1177/0539018419897001

Table 2. Articles published in ethics, social science and social work journals

\begin{tabular}{|l|c|}
\hline Web of Science category & Number of articles \\
\hline Economics & 4 \\
\hline Cultural studies & 5 \\
\hline Law & 5 \\
\hline Social sciences interdisciplinary & 10 \\
\hline Family studies & 10 \\
\hline Social work & 14 \\
\hline Medical ethics & 18 \\
\hline Ethics & 19 \\
\hline Sociology & 20 \\
\hline Social issues & 23 \\
\hline History/philosophy of science & 24 \\
\hline Anthropology & 27 \\
\hline Social sciences biomedical & 34 \\
\hline
\end{tabular}

Thus, the primary interest of social epigenetics is to study associations between social environments, epigenetic modifications and the development of psychopathologies. In the following section, I will show that research studying psychosocial stress defined as social defeat (in animals), early-life adversity (in animals) and childhood trauma (in humans) amounts to half of the publications in social epigenetics. But social epigenetics studies other health-related outcomes (cancer, immune diseases, metabolic diseases, etc.) in relation with other social environments. Other bibliometric tools are needed to provide a detailed description of these various research areas. In particular, in the following section, I analyze co-citation networks to characterize the cognitive structure of social epigenetics. The analysis of co-citations - two references cited in the same article - is based on the idea that co-citations represent an indicator of proximity in terms of content (Andrés, 2009). Therefore, co-citation networks are useful to identify 'the epistemic foundations of the research community, which consists of groups of seminal works shared by the various sub-communities' (Raimbault, Cointet \& Joly, 2016).

The co-citation analysis allowed me to identify five clusters of references which are frequently cited together (Graph 1). These clusters delineate five sub-corpuses with distinct epistemic backgrounds. Of these, there are two sub-corpuses on animal research and three on human studies. In the next section, I will describe five epistemic backgrounds of epigenetics which clearly emerge from these five clusters of co-cited references. In the last section, I will address how the social sciences have engaged with research areas of social epigenetics conducting human studies. 
To cite this article Louvel, S. (2020). What's in a name? The three genealogies of the social in social epigenetics. Social Science Information. https://doi.org/10.1177/0539018419897001

Graph 1. The five epistemic backgrounds of epigenetics (co-citation network)

early trauma

(humans)

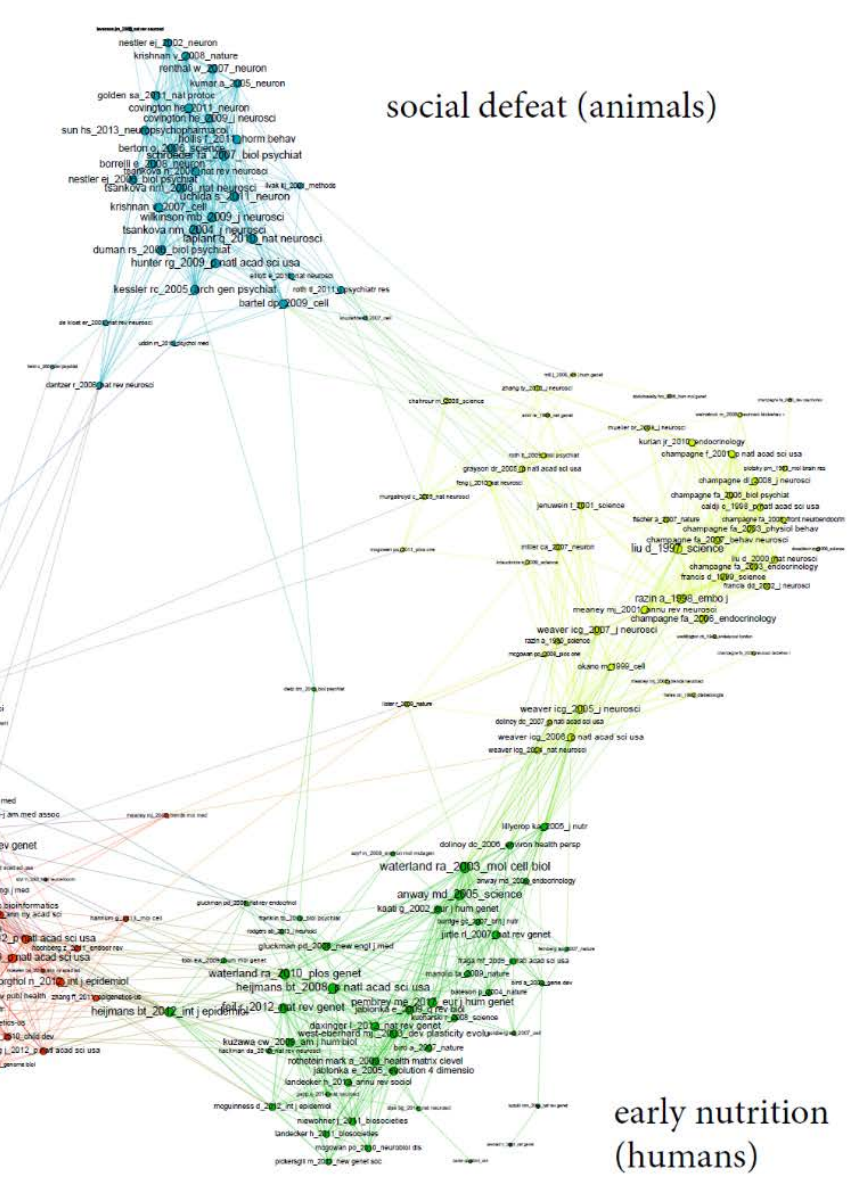

early adversity (animals)

\section{The five epistemic backgrounds of social epigenetics}

While half of the articles in social epigenetics (about 52\%) focused on psychosocial stress in animals or in humans (with clusters on social defeat, early trauma and early adversity), more than a third studied early-life nutrition (early nutrition cluster) and the remaining 20\% investigated cumulative social experiences (life-course cluster). Human research became more prominent, representing more than $60 \%$ of articles in 2018 versus less than $40 \%$ in the early 2010s. To analyze commonalities and differences between the epistemic backgrounds of social epigenetics, I relied not only on their dominant features (e.g. most prolific authors, most frequent keywords), but also on their specific characteristics (see Table 4 in the annex). For example, all clusters include articles from the WOS category 'pharmacology' - which points to a common search for preventive or curative 'epigenetic' treatments. At the same time, this WOS category is more specific to the 'social defeat' cluster - which indicates that research from this cluster is more deeply committed to developing targeted molecular interventions. Finally, I qualitatively analyze foundational and recent articles to provide an epistemological reflection on each cluster. More specifically, I ask what type of scientific evidence the articles aim to establish (e.g. is the goal to identify associations or to draw causal links between social environments, epigenetic changes and health effects?). I also report on disagreements and controversies within each cluster that pertain to either the scientific validity of social epigenetics or to its relevance for therapeutic applications and policy interventions. 
To cite this article Louvel, S. (2020). What's in a name? The three genealogies of the social in social epigenetics. Social Science Information. https://doi.org/10.1177/0539018419897001

Graph 2. Distribution of the corpus between the five epistemic backgrounds

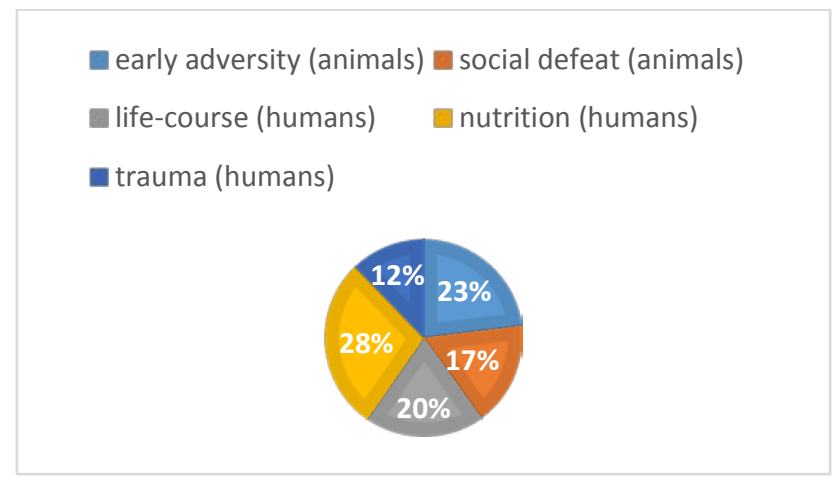

The 'social defeat' and 'early adversity' sub-corpuses gather articles on research in animal behavioral models. In both clusters, animal models are conceived of as 'technologies of translation' from animal research to human research (Shostak, 2007). Although researchers warn against the complications of using data from animal models to predict human behavioral responses, they repeatedly emphasize that animal models - in particular, rodent behavioral models - 'continue to represent the most efficient approach to elucidating the molecular and cellular mechanisms that underlie the etiopathogenesis of psychiatric disorders' (Zannas \& West, 2014). Indeed, animal models make it possible to reproduce experiments under controlled conditions. Moreover, by accessing brain tissues, researchers hope to go beyond the detection of associations between exposure and behavior to identifying biological pathways or causal chains from exposure to behavior. However, to date, this objective has rarely been achieved.

\section{'Social defeat' in rodents}

The first sub-corpus analyzes the epigenetic modifications triggered by exposure of adult rodents to so-called 'social stress'. These articles are predominantly published in the Web of Science categories of neuroscience, psychiatry, and pharmacology/pharmacy. Researchers experimentally induce social stress in animals using standardized protocols. For instance, mice are 'repeatedly subjected to bouts of social defeat by a larger and aggressive CD-1 mouse' (Golden et al., 2011). In a foundational paper published in 2006, Tsankova et al. study social defeat stress because it induces behavioral and mental disorders: 'To better understand the molecular mechanisms of depression and antidepressant action, I administered chronic social defeat stress followed by chronic imipramine (a tricyclic antidepressant) to mice [...] These experiments [...] highlight the therapeutic potential for histone methylation and deacetylation inhibitors in depression.' (Tsankova et al., 2006) They use social stress models to develop depression-like symptoms in adult rodents (e.g. social avoidance). Their expectations towards epigenetics are twofold. First, they aim to unravel the molecular mechanisms leading from social stress situations to psychiatric disorders in humans (e.g. depression and schizophrenia) which have been associated with various psychosocial factors, for which there is no experimentally-controlled exposure. Second, they seek to reverse the epigenetic modifications induced by stress with targeted interventions and to develop epigenetic treatments of psychiatric disorders. However, as noted in a recent review paper, the research is not yet adequate: 'It is not trivial to determine whether stimulusdependent changes in DNA methylation are regulatory (i.e. causative for changes in gene transcription and subsequent behavioral plasticity) or merely an epiphenomenon reflecting changes in gene activation' (Zannas \& West, 2014). 
To cite this article Louvel, S. (2020). What's in a name? The three genealogies of the social in social epigenetics. Social Science Information. https://doi.org/10.1177/0539018419897001

Graph 3. Cluster on social defeat in rodents



Early-life adversity in animal models

The second sub-corpus gathers research from the behavioral sciences and biological psychology. Researchers analyze how so-called negative 'early social environments' influence the development and activity of the central nervous system, and what the behavioral, cognitive and psychiatric consequences are (such as learning impairments, enhanced sensitivity to drug abuse, and increases in anxiety and depression-related behaviors) (Lupien et al., 2009). Ultimately, they aim to design pharmaceutical interventions to rescue aberrant gene expression due to early-life adversity (Roth et al., 2009). A foundational study is the paper by Weaver and colleagues on the 'epigenetic programming to stress' of rat pups by maternal behavior and care (Weaver et al., 2004). They found an association between maternal care during the first week of postnatal life and the methylation status of the glucocorticoid receptor (GR) gene promoter in the hippocampus of the offspring. They also found that these epigenetic differences persisted into adulthood. They concluded that 'these findings suggest that variations in maternal behavior serve as a mechanism for the nongenomic transmission of individual differences in stress reactivity across generations' (Weaver et al., 2004: 847). Geneticists and molecular biologists have been very skeptical about the hypothesis of 'epigenetic programming to stress' through maternal care. They have argued that 'the behavioral scientists' data [...] are highly correlative, and the underlying mechanisms are still largely unknown' (Buchen, 2010); and in addition, that methylation changes are 'tiny, appearing on only a handful of nucleotides in a small region of a gene, for example. And those changes only occur in a fraction of the total cells' (Buchen, 2010). However, a wealth of studies ensued to corroborate initial associations between early-life social environments and stress responses. Researchers studied epigenetic marks at several genes - the GR gene, the brain-derived neurotrophic factor (BDNF) gene - and at specific locations on those genes. They used a variety of animal models - mainly rodents and rhesus monkeys - to experimentally control and standardize early-life environments as well as to study epigenetic modifications in brain tissues (Champagne, 2012). The studies largely define early social environments by 'early-life adversity' inflicted by prenatal stress and by poor 'quality of postnatal mother-infant interactions' 
To cite this article Louvel, S. (2020). What's in a name? The three genealogies of the social in social epigenetics. Social Science Information. https://doi.org/10.1177/0539018419897001

(Champagne, 2012). Researchers used several standardized protocols for inducing early-life adversity: presence or lack of maternal care (e.g. frequent nursing and licking/grooming of offspring), maternal deprivation (e.g. through rearing of infant rhesus macaques in a nursery), prolonged maternal separation (e.g. 1-3 hours per day throughout the postnatal period in rodents) and maternal abuse (e.g. dams stepping on pups, aggressive grooming, and dragging of pups by a limb (Champagne, 2012). This area of social epigenetics has established associations between early-life adversity, epigenetic modifications and stress responses in very different experimental situations (Turecki \& Meaney, 2016). However, epigenetic modifications are part of a complex biological machinery which makes imminent clinical applications highly unlikely: 'It is perhaps not surprising that clinical progress such as the development of biomarkers for ELA/MDD (major depressive disorders) and antidepressant therapies that target the epigenome - has thus far been limited and preliminary'. (Brown, Fiori \& Turecki, 2019)

Graph 4. Cluster on early life adversity in animal models

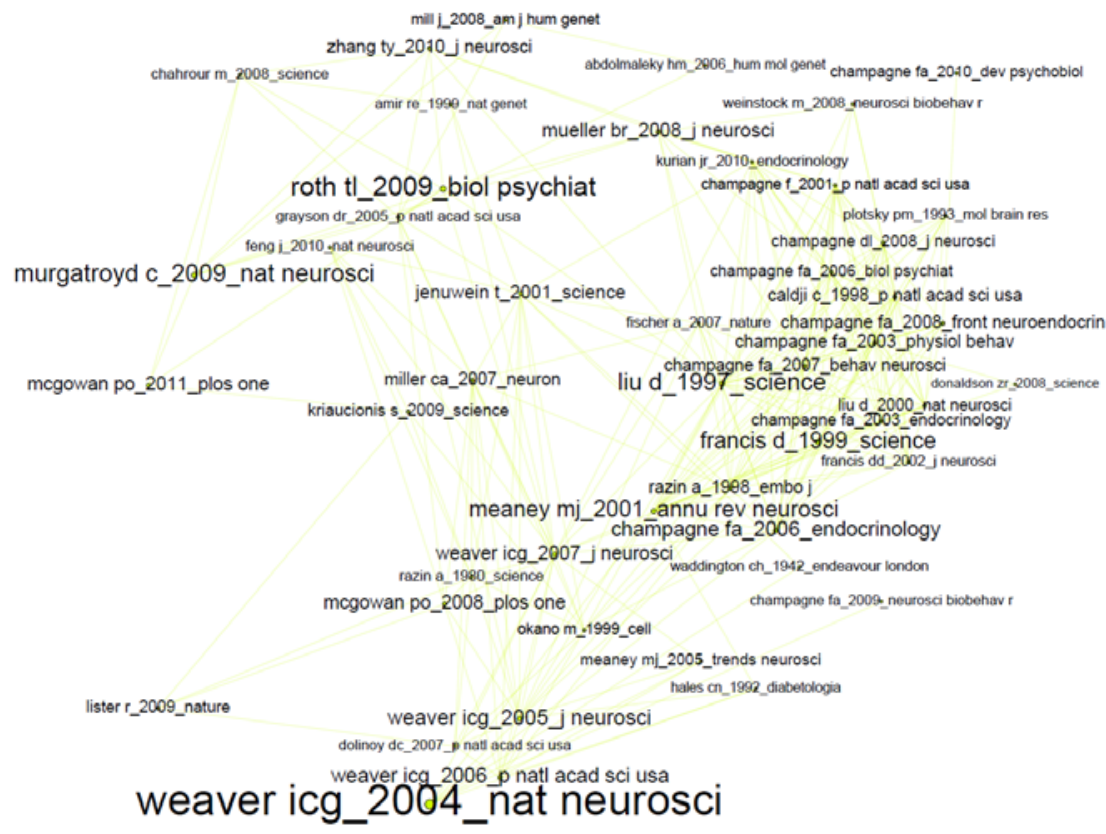

Research gathered in the three remaining sub-corpuses conducts epidemiological studies of human cohorts. Researchers collected biological material from participants - blood samples, buccal cells, umbilical cord, etc. - and looked for associations between exposures to various kinds of social environments, epigenetic modifications and health outcomes. Much research has drawn on animal research on the epigenetic effects of 'early adversity' to identify genes in which to investigate epigenetic changes associated with social adversity. Lastly, inconsistent observations or lack of biological significance has mitigated the hope of finding epigenetic biomarkers of social experiences.

\section{Childhood trauma}

Articles in this sub-corpus question how epigenetic modifications mediate the relation between acute psychosocial stress early in life (in particular, traumatic events in childhood or exposure to acute parental stress such as PTSD) and the onset of psychiatric disorders later in life. Studies by McGowan et al. and Labonte et al. on the links between childhood trauma, epigenetic modifications and the increased risk of suicide later in life are foundational for this area of social epigenetics (McGowan et al., 2009; Labonte et al., 2012). McGowan et al. found epigenetic differences 'between postmortem 
To cite this article Louvel, S. (2020). What's in a name? The three genealogies of the social in social epigenetics. Social Science Information. https://doi.org/10.1177/0539018419897001

hippocampus obtained from suicide victims with a history of childhood abuse and those from either suicide victims with no childhood abuse or controls'. The authors present their work as a direct translation to humans of the Weaver et al. study on rats, made possible by access to human brain tissue from the Quebec Suicide Brain Bank and to personal histories of childhood abuse: 'I had never expected to have a chance to work with human samples,' McGowan says. 'But the feeling was that if I can do this in animals, why not in humans? I had the brains, and I had the histories. ${ }^{4}$ This area of social epigenetics is anchored in the neurosciences, psychiatry, and developmental psychology. Most articles are published in psychiatry and educational psychology journals. Researchers studied cohorts of 'controlled' (i.e. non-exposed) and exposed individuals (either adults exposed to psychosocial stress early or children exposed to parental prenatal stress). Stressful events are often self-reported. Early-life social stress is for instance assessed using the Childhood Trauma Questionnaire (a brief survey of six early traumatic experiences: death, divorce, violence, sexual abuse, illness or other) while parental prenatal stress is associated with a variety of stressors on expectant mothers, such as the experience of anxiety and mood disorders, pregnancy-related anxiety, violence, or war stress during pregnancy (Turecki \& Meaney, 2016). Some articles also gathered measures of social relationships such as social support, e.g. whom the child could confide in to talk about personal issues or count on to purchase needed materials/objects; socioeconomic burden; or 'family life' i.e. quality of parenting (White et al., 2015).

Researchers have studied the genes involved in stress responses for which animal research has established associations between exposure to stress and epigenetic modifications - in particular, the NR3C1 gene, which codes for the glucocorticoid receptor (Palma-Gudiel et al., 2015), the FKBP5 gene which modulates stress responses (White et al., 2015) and the serotonin transporter gene (Provenzi et al., 2016). The researchers' main expectations towards epigenetics was to identify the mechanisms leading from psychosocial stress early in life to a higher risk of depression and anxiety disorders. Eventually, their aim is to develop epigenetic biomarkers which can predict the type and severity of the psychopathology favored by early-life acute psychosocial stress; it is also to reverse the effects of acute stress. However, researchers noted that there is still a long way to go before the development of treatment-based interventions, in particular because the biological significance of epigenetic modifications is still not fully understood. For example, the authors of a meta-analysis of DNA methylation of the serotonin transporter gene concluded that: 'The possibility that exposure to adversities might result in either an increase or a decrease in serotonin transporter gene methylation could not be ruled out [...] [this] should be considered as a biologically-based warning against reductionist interpretation of DNA methylation as a direct marker of detrimental developmental conditions' (Provenzi et al., 2016).

\footnotetext{
${ }^{4}$ Source: https://reporter.mcgill.ca/the-legacy-of-child-abuse/
} 
To cite this article Louvel, S. (2020). What's in a name? The three genealogies of the social in social epigenetics. Social Science Information. https://doi.org/10.1177/0539018419897001

Graph 5. Cluster on childhood trauma

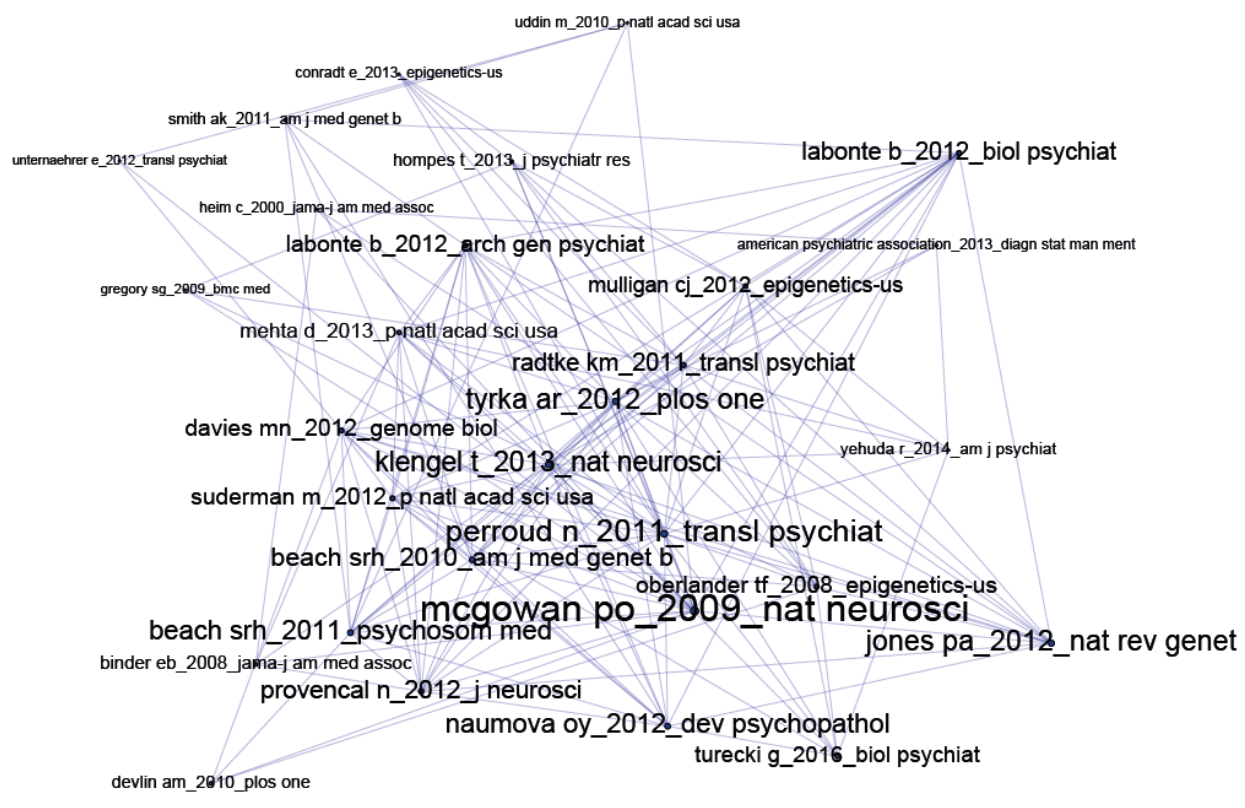

\section{Early-life nutrition}

The fourth sub-corpus investigates the socioeconomic roots of the current world-wide spread of cardiovascular diseases and type-2 diabetes. This area of social epigenetics stems specifically from epidemiology, endocrinology and metabolism, and contributes to research on the Developmental Origin of Health and Disease hypothesis (DOHaD). While I present in detail how the social sciences engage with social epigenetics in the next section, it is worth noting that a specific feature of this subcorpus is the significant number of articles published in social science and ethics journals (about 40 articles) as well as the presence of several sociological papers among the most frequently co-cited references in this cluster (Landecker, 2011; Niewöhner, 2011; Landecker \& Panofsky, 2013).

This sub-corpus includes original articles and review papers in public health, endocrinology and metabolism. This research uses evidence from nutritional epigenetics to support the DOHaD hypothesis. This hypothesis is seen as having introduced a paradigmatic shift in epidemiology from the late 1980s onwards. It can be summarized as follows: the early-life environment matters more than the current lifestyle for explaining health inequalities throughout life (Barker, 1990). Initially, researchers working on the DOHaD hypothesis focused on the long-term effects of early-life nutrition, before including early psychosocial stress and exposures to toxicants and pollution. Epidemiologists and physiologists have collaborated since the 1990s on animal models to 'provide first proof that early life exposures (nutritional, infective, biochemical) had lifelong effects' (Hanson, 2015). In the 2000s, $\mathrm{DOHaD}$ researchers saw epigenetic modifications as biological mechanisms through which 'nutritional imbalance and metabolic disturbances early in life may later have a persistent effect on an adult's health that may even be transmitted to the next generations' (López-Jaramillo et al., 2008). ${ }^{5}$ In a foundational study, Heijmans and colleagues (Heijmans et al., 2008) used the Dutch Hunger Famine

\footnotetext{
${ }^{5}$ The International Society for Developmental Origins of Health and Disease promotes research into the fetal and developmental origins of disease, with over 550 members from 55 countries worldwide: $\underline{\text { https://dohadsoc.org/ }}$
} 
To cite this article Louvel, S. (2020). What's in a name? The three genealogies of the social in social epigenetics. Social Science Information. https://doi.org/10.1177/0539018419897001

as a 'natural experiment' to test hypotheses established by animal research. ${ }^{6}$ They showed that 'individuals who were prenatally exposed to famine during the Dutch Hunger Winter in 1944-45 had, 6 decades later, less DNA methylation of the imprinted IGF2 ${ }^{7}$ gene compared with their unexposed, same-sex siblings [...] a key factor in human growth and development' (Heijmans et al., 2008). A series of articles reported associations between the rise of cardiometabolic diseases in low- and middle-income countries, the rapid socioeconomic and nutritional transitions they are experiencing either restriction or rapid increase - and epigenetic modifications. These articles argue that the 'mismatch' between 'epigenetic programming' to undernutrition during fetal life and an abundance of high-calorie food after birth puts individuals at high risk for these diseases. Another series of articles studied early-life nutrition, parental lifestyle and stress, and their combined effects on metabolic diseases and neurological disorders. For instance, the cohort study GUSTO (Growing Up in Singapore Towards healthy Outcomes) recruited 1,247 expectant mothers of Chinese, Malay, or Indian ethnicity in their first trimester, with longitudinal tracking of mothers, fathers and children during pregnancy and the child's first 4 years of life (Soh et al., 2014). ${ }^{8}$

Articles described two possible outcomes for their research. First, it might help design targeted treatments and interventions: 'The research aims to provide biomarkers reflecting cause-and-effect relations along developmental pathways for designing interventions and stratifying populations for more effective targeting of interventions' (Soh et al., 2014). In particular, this area of social epigenetics proposes a whole range of nutritional interventions to pregnant mothers and infants. However, progress in this area is slower than expected and studies disagree on the effects of maternal nutrition - in particular, the amount of micronutrients which provide methyl groups such as folate, choline, betaine and other B vitamins - on the offspring epigenome (Richmond \& Joubert, 2017). Thus, it may help establish priorities in health policies. In particular, the 'epigenetic programming' of non-communicable diseases during early-life should advocate for making children and teenagers the primary target of non-communicable disease prevention policies: 'It is now becoming clear that satiety, food preference and perhaps exercise capacity (at least in animals) have major developmental and biologically-based determinants. Once set points are established in early life (with both prenatal and early postnatal components), it may be effectively impossible to reverse these and this may explain why lifestyle interventions are difficult to sustain' (Hanson \& Gluckman, 2015). This idea is not fully accepted by epidemiologists: 'DOHaD [...] has been somewhat dismissive of the potential for later-life interventions to modify disease risk or alter disease progression. A life-course approach is essentially agnostic and tries to provide empirical evidence to guide the most appropriate timing of any intervention' (Ben-Shlomo, Cooper \& Kuh, 2016).

\footnotetext{
${ }^{6}$ In particular, research by Waterland and Jirtle on agouti mice pioneered nutritional epigenetics (Waterland \& Jirtle, 2003).

${ }^{7}$ Insulin-like growth factor II.

${ }^{8}$ Data collection included: demographic and lifestyle data (mother and father), physical health (mother and father), mental health (mother), obstetric data (mother), diet and nutrition (mother and child), physical examination (mother, father and child), biospecimen collection (mother, father and child), fetal anthropometry (child), and cognitive function (child).
} 
To cite this article Louvel, S. (2020). What's in a name? The three genealogies of the social in social epigenetics. Social Science Information. https://doi.org/10.1177/0539018419897001

Graph 6. Cluster on early-life nutrition

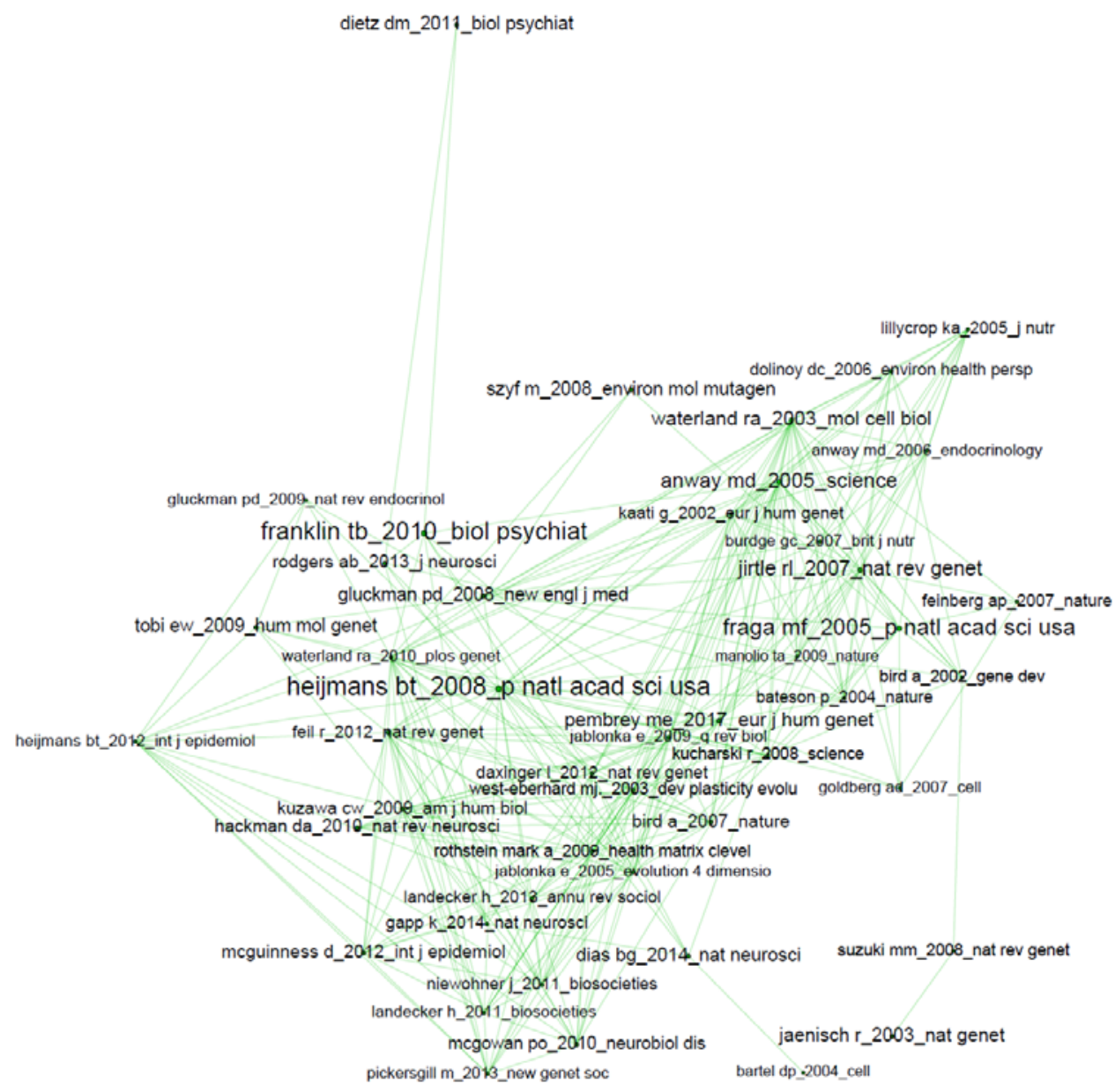

\section{Social adversity over the life-course}

The fifth sub-corpus gathers research on how social adversity experienced on a daily basis impacts health later in life. It studies situations of common social adversity experienced during childhood, adolescence and/or adulthood. This sub-corpus features two main approaches to social adversity and its links to disease risk during the life-course.

In the first stream, research in developmental psychology, psychology and psychopathology addresses how social adversity during childhood and teenage years puts young adults at higher risk for behavioral problems and psychopathological disorders such as depression, substance abuse, and aggressive behavior. The article by Essex and colleagues partly sets the foundations for this field (Essex et al., 2013). The authors wished to extend analysis of the long-term consequences of childhood maltreatment to the study of 'day-to-day misfortunes': 'It is often the less memorable yet prevalent, co-occurring, day-to-day misfortunes of early childhood (e.g., impoverished parent-child interactions) that have a lasting influence on the subsequent life course' (Essex et al., 2013). Essex et al. used parental reports of adversity during the adolescents' infancy and preschool periods. For each parent, they established stress scores combining depression symptoms, family-expressed anger, parenting stress, role overload, and financial stress. They also measured DNA methylation levels in 109 fifteen-year-old adolescents, and found that adolescents whose parents experienced high levels of stress during their upbringing had a different methylation profile. However, they noted that the biological significance and health consequences of these differences in methylation have yet to be 
To cite this article Louvel, S. (2020). What's in a name? The three genealogies of the social in social epigenetics. Social Science Information. https://doi.org/10.1177/0539018419897001

established. ${ }^{9}$ Later, other authors operationalized these 'day-to-day misfortunes' in different ways, using, for example, measures of neighborhood crime (Lei et al., 2015) or measures of social relations and childhood trauma in a population of low socioeconomic status (Kogan et al., 2018). Researchers have sought associations between these forms of social adversity and epigenetic modifications in genes whose regulation is involved in psychopathological disorders, such as the serotonin transporter gene.

In the second stream, research in developmental psychology, social epidemiology and public health questions the impacts of daily social adversity on the preservation or deterioration of physical health. Researchers' interest in the physiological consequences of stress caused by social adversity is rooted in findings that bodies respond to stress in ways which cause the 'dysregulation of multiple physiological structures, including the cardiovascular, metabolic, autonomic, endocrine, and inflammatory systems' (Brody, Yu \& Beach, 2016). Miller and colleagues and Borghol and colleagues published the first papers on the influence of socioeconomic position on disease susceptibility (Miller et al., 2009; Borghol et al., 2012). Both articles draw on research on early-life adversity in rodents: 'Miller says he expected to find increased methylation of the glucocorticoid receptor gene studied by Meaney's group, reasoning that the lower socioeconomic environment of his subjects might be roughly analogous to the un-nurturing environment of Meaney's rat pups' (Miller, 2010). Their conclusions, however, were strikingly different: Borghol and colleagues found that Socio-Economic Position (SEP) during childhood was significantly associated with DNA methylation at adult age, while Miller and colleagues identified links between SEP in childhood and the activity of more than 100 genes involved in the immune system, but found few significant links to the methylation of these genes. ${ }^{10}$ Current research has provided several definitions of common negative social experiences and has sought to associate them with targeted or more global epigenetic modifications. Definitions of 'day-to-day' social adversity have included: pre-adolescence 'cumulated SEP-related risk' ${ }^{11}$ among a population of rural African-American youth (Brody, Yu \& Beach, 2016); economic hardship, downward mobility, neighborhood poverty, and racial discrimination among the same population of African-American youth (Simons et al., 2016); and life-course SEP trajectories taking the father's occupational position as a proxy for early-life SEP and highest occupational position as a proxy for adulthood SEP in three independent prospective cohorts from Italy, Australia and Ireland (Fiorito et al., 2017). In addition, while some research focuses on specific genes - notably genes involved in stress response - others use 'epigenetic clocks' to measure global individual epigenomic states. An epigenetic clock is an 'age predictor based on DNA methylation levels' ${ }^{12}$ used to predict the onset of age-related diseases. In social epigenetics, research groups use epigenetic aging as a biomarker of the 'biological weathering' effects of living in a socially-deprived context. For instance, Miller and colleagues found an association between self-control - 'the ability to resist temptations that interfere with long-term aspirations' - in 292 African-American teenagers from rural Georgia - and the accelerated epigenetic aging of their immune cell systems at age 22. They argued that for low-SEP youth, self-control has positive psychosocial consequences but negative biological consequences (Miller et al., 2015).

To sum up, this fifth sub-corpus aims at establishing 'life course biological pathways' (Vineis et al., 2017) through which widespread situations of social adversity can be said to travel 'under the skin'. Researchers hope to use epigenetic biomarkers in two ways: to identify at-risk populations for psychopathological disorders in order to target these populations for prevention campaigns and personalized treatments; and to evaluate the health effects of behavioral and social interventions such

\footnotetext{
${ }^{9}$ In addition, the authors pointed out that significant differences in methylation do not involve genes that play a role in stress regulation. Contrary to results obtained in animal research, differences in methylation cannot therefore be associated with altered stress responses.

${ }^{10}$ For a report on this controversy see Miller (2010).

${ }^{11}$ Brody et al., 2016. This score combines six indicators: family poverty, primary caregiver non-completion of high school or an equivalent, primary caregiver unemployment, single-parent family structure, family receipt of Temporary Assistance for Needy Families, and income rated by the primary caregiver as not adequate to meet all needs.
}

12 Two versions of the epigenetic clock have been independently published. Source: https://stresscenter.ucsf.edu/measures/epigenetic-clock 
To cite this article Louvel, S. (2020). What's in a name? The three genealogies of the social in social epigenetics. Social Science Information. https://doi.org/10.1177/0539018419897001

as the promotion of supportive family environments: 'From a public health perspective, this study, along with the others described in this section, shows that developmentally-appropriate prevention programs designed to enhance supportive parenting can ameliorate the effects of contextual risk factors on health-relevant outcomes that are evident at the cellular level' (Brody, Yu \& Beach, 2016). However, researchers point to several bottlenecks in social epigenetics. They report difficulties in comparing results due to multiple ways of objectifying social situations and measuring epigenetic changes, as well as the issue of generalizing results obtained from highly-traumatized cohorts (Zannas et al., 2015). They also question reasons for inconsistent observations - for instance, some studies have found that the methylation of genomic regions regulating immune function is associated with childhood SEP, while other studies have found associations with indicators of SEP in adulthood (Stringhini et al., 2015) or with cumulative life stress (Zannas et al., 2015). Lastly, researchers point to the lack of demonstrated causal links between social situations, epigenetic changes and health states (Brody, Yu \& Beach, 2016).

Graph 7. Cluster on social adversity over the life-course



The social sciences and human studies in social epigenetics: three modes of engagement

In this last section, I will show that the social sciences have developed three modes of engagement with human studies in social epigenetics. I will also argue that the third mode - support and contribution - addresses recent claims that social epigenetics may become an inter-discipline between the social and natural sciences. I will show that this mode of engagement - which involves 
To cite this article Louvel, S. (2020). What's in a name? The three genealogies of the social in social epigenetics. Social Science Information. https://doi.org/10.1177/0539018419897001

sociologists studying family, aging, health and crime - is still relatively unknown, even though it lies at the heart of the promise to make social epigenetics an inter-discipline.

\section{Rejection: Social epigenetics trapped in the 'social brain' and 'neuromania'}

In this first mode of engagement, social science researchers criticize research in social epigenetics anchored in the neurosciences, psychiatry, and developmental psychology which focuses on the epigenetic links between acute stress and psychopathological disorders. These critical views are found mostly in anthropological and sociological journals, but also in journals of social work (e.g. The British Journal of Social Work), thus reaching a professional audience. The criticism is aimed primarily at human studies (sub-corpus 'childhood trauma'). To these critics, epigenetic and neuroscientific modes of inquiry or 'styles of reasoning' (Lloyd \& Raikhel, 2018) are similar in three ways. First, they focus on the early programming of the 'social brain' (i.e. how social experiences shape brain functions, and with what behavioral consequences): 'Overall, these neuroscience and epigenetic models suggest that particular life experiences, especially early experiences, leave lasting traces in the brain, rendering an individual and potentially his or her descendants, through a variety of mechanisms, susceptible to suicidal behaviour' (Lloyd \& Raikhel, 2018). Second, they draw highly reductionist definitions of social experiences - in particular of maternal stress - from experiments on animals (White \& Wastell, 2016; Kenney \& Müller, 2017). Lastly, this area of epigenetics may revive and nurture expectations aroused by the 'neuromania' of the 1990s and 2000s (Macvarish, Lee \& Lowe, 2014). In particular, its focus on parental stress and lack of care for children conveniently supports conventional wisdom about the importance of parenting to the child's development, which has gained traction in social policies (White \& Wastell, 2016) ${ }^{13}$ and among social workers. At the same time, the social conditions conducive to stressful situations remain largely unquestioned. White and Wastell (2016) give the counter-example of the Ice Storm Project in Quebec, which recruited women who had been pregnant during the disaster and assessed their degrees of objective hardship and subjective distress. The study concluded that epigenetic effects were due to objective hardship rather than from perceived stress resulting from this situation (Cao-Lei et al., 2014).

Warning and calls for responsibility: Social epigenetics between structural social conditions and individualized monitoring

In this second mode of engagement, social scientists discuss the area of social epigenetics which has its main roots in epidemiology, endocrinology and metabolism, and which focuses on the health effects of under- and over-nutrition, alone or combined with 'stressors' such as psychosocial stress and exposure to pollutants (sub-corpus on 'nutrition'). First, they criticize this research for viewing food as an individual choice rather than as a set of culturally, economically and socially embedded practices. They also denounce the possible conflation between association - between maternal nutrition and health outcomes in the offspring - and causation, because of unobserved confounders (Sharp, Lawlor \& Richardson, 2018). However, these critics express less an upfront rejection of this area of social epigenetics than a certain disillusion towards its initial promises. For instance, Warin and colleagues stress that nutritional epigenetics may only further deviate the DOHaD hypothesis from a fight against the socioeconomic roots of disease risk towards the attribution of maternal responsibilities for their children's health: 'The development origins of health and disease has transformed from a concept that highlighted the interaction between a country's socioeconomic status and the disproportionate exposure of women to obesogenic factors [...] to a narrow understanding that locates the reproduction of obesity in the interiors of women's bodies' (Warin et al., 2011).

There are also mixed opinions concerning the ethical and policy implications of this area of social epigenetics. While some social science scholars warn against early signs of the intensification of women's maternal responsibilities for their children's obesity, others emphasize the political malleability of epigenetics: 'As with genetics, insights from epigenetics can present both means of

\footnotetext{
${ }^{13}$ See for instance the paper by Strong and Combs-Orme which argues for the 'usefulness of animal models of research for social workers, specifically in the areas of maternal care and the childhood experience, and dementia.' (Strong \& Combs-Orme, 2018)
} 
To cite this article Louvel, S. (2020). What's in a name? The three genealogies of the social in social epigenetics. Social Science Information. https://doi.org/10.1177/0539018419897001

empowerment - to understand the links between social location and health outcomes - but also means of possible discrimination' (Saldaña-Tejeda, 2018) ${ }^{14}$ Ethicists and philosophers have argued that the jury is still out as to the implication of social epigenetics in intergenerational equity (Loi, Del Savio \& Stupka, 2013) and in environmental justice: '[Epigenetics] could shift the focus from populations receiving disproportionate exposure to those with greater susceptibility. Second, rather than focusing on geographically-defined communities, it concentrates on the individual biological factors that establish increased risk [...] It remains to be seen whether emerging scientific evidence of epigenetic effects, including transgenerational effects, will be a catalyst for environmental justice' (Rothstein, Cai \& Marchant, 2009).

Lastly, several social science articles target natural scientists. They are published in biological and medical journals - such as Annals of Human Biology, EMBO Reports (European Molecular Biology Organization), Environmental Epigenetics, or The Lancet Diabetes \& Endocrinology - and some of them are co-published with prominent figures of the DOHaD international society (e.g. Mark Hanson, Professor of Cardiovascular Science, founder member and ex-President of the International Society for the DOHaD). These articles aim to put nutritional epigenetics back on track by two means. First, they use social constructivist accounts of science so as to increase natural scientists' reflexivity on the scientific process: 'Exactly what phenomena am I making real with my research? Which categories do I use to describe and label that which I seek to explore? Which silent assumptions about the social world might I integrate into my research designs and the interpretation of my results, possibly without further reflection?' (Hanson \& Müller, 2017) Then, they call for more interdisciplinarity between the natural and the social sciences so as to more directly address the social roots of health disparities: 'Researchers argue that maternal obesity might increase the offspring's risks of diabetes and cardiovascular disease, and might even negatively affect cognitive performance. We know, however, that the risk of obesity is unevenly distributed throughout society. [...] We need to start a conversation that relates epigenetic findings more strongly to questions of social and environmental justice.' (Hanson \& Müller, 2017)

\section{Support and contribution: Social epigenetics strengthening social studies of health}

Lastly, some sociologists seize upon social epigenetics to question the long-term health effects of social adversity over the life-course. This third mode of engagement is displayed in a small number of articles co-written with researchers from developmental psychology, social epidemiology and public health. They are published in journals in the biomedical social sciences (e.g. Social Science \& Medicine), criminology (Criminology) and psychology (Developmental Psychology, Development and Psychopathology). These interdisciplinary collaborations differ from those associated with the second mode of engagement. Indeed, they are neither programmatic, nor oriented towards a critical appraisal of research in social epigenetics. Rather, researchers use epigenetics to decipher the biological pathways that link social conditions (such as low income, neighborhood violence, or racial discrimination) to poor health. Articles published by researchers from the Center for Family Research at the University of Georgia, USA - for instance, Simons et al. (Simons et al., 2016) and Lei et al. (Lei et al., 2015) - follow this approach to social epigenetics. They associate sociologists interested in family, aging, social determinants of health inequalities and criminology (Ashley Barr, Man-Kit Lei, Robert L. Simons) with researchers in psychology and in psychiatry. To these sociologists, social epigenetics seems to offer unique opportunities to establish 'biosocial' models of health without 'biologizing' the social. Some of them have fought against the 'genetics of crime' within criminology for this very reason. In particular, Robert L. Simons has fiercely criticized the use of genetic studies to investigate the heritability of criminal behavior and to attempt to separate genetic from environmental effects (Burt \& Simons, 2014). On the contrary, Simons uses social epigenetics to show that 'genes do not operate in isolation; rather, they interact with environmental conditions' (Simons et al., 2016).

\footnotetext{
${ }^{14}$ See also Meloni \& Müller, 2018.
} 
To cite this article Louvel, S. (2020). What's in a name? The three genealogies of the social in social epigenetics. Social Science Information. https://doi.org/10.1177/0539018419897001

\section{Conclusion}

In this paper, I have analyzed how research in social epigenetics characterizes the social environments which presumably get 'under the skin' through epigenetic mechanisms. Using bibliometric data and a qualitative analysis of foundational and recent research in social epigenetics, I have identified several scientific approaches to social epigenetics. All of these search for associations between social environments and epigenetic modifications, but differ according to the scientific areas involved, the definition of 'social', the use of models and data, and the practical expectations towards epigenetics. I have also characterized distinct modes of engagement of the social sciences with social epigenetics. This analysis contributes to the growing body of critical social science literature on epigenetics - and more generally, on the rise of 'biosocial' models of health in the biological sciences - in several ways.

First, I have given a comprehensive view of social epigenetics, relating it to five epistemic backgrounds. When studying animals, social epigenetics either approximates social environments by 'social defeat' - taking models from the neurosciences and psychiatry - or by 'early-life adversity', drawing from the behavioral sciences. When conducting human studies, social epigenetics mainly operationalizes the social via 'childhood trauma' - relying on psychiatry and developmental psychology, 'early-life nutrition' - extending endocrinology and epidemiology, and by 'social adversity over the life-course' - following insights from developmental psychology, social epidemiology and the sociology of criminality and health. While the biological significance of associations observed in animal models remains unclear, human studies struggle with inconsistent observations. However, the search for epigenetic markers of adverse social environments raises high expectations: identifying at-risk populations, developing drugs, proposing prevention campaigns and behavioral as well as social interventions.

Secondly, I have differentiated between three modes of engagement of the social sciences. The epigenetics of 'childhood trauma' - the search for epigenetic links between early-life acute stress and psychopathological disorders - has received harsh criticism from the social sciences due to its association with the search for the 'social brain' and fear of a revival of 'neuromania' in policy circles. The epigenetics of 'early-life nutrition' - the epigenetic mediation between under- and over-nutrition during fetal and postnatal life, and adult chronic diseases - raises mixed opinions on concerns and calls for interdisciplinary collaboration, with social scientists urging natural scientists to 'bring the social back' into this area of social epigenetics and to move it away from its focus on individual lifestyles. In addition, the epigenetics of 'social adversity over the life-course' includes several joint initiatives from sociologists, psychologists or epidemiologists using epigenetics as a biomarker of the association between various social experiences, health and disease.

Thirdly, the present paper has shown that sociological inquiry into social epigenetics has focused so far on the epigenetics of childhood trauma and of early-life nutrition. This inquiry criticizes its impoverished approaches to the social - coming from the transposition of animal research to human studies, or from the black-boxing of all social influences whose biological effects cannot be easily measured. On the contrary, the sociology of epigenetics has so far paid little attention to the epigenetics of social adversity over the life-course. Sociologists of epigenetics acknowledge early attempts to measure the epigenetic imprint of socioeconomic disadvantage, for example in research by Borghol, and McGuiness and colleagues (Borghol et al., 2012; McGuinness et al., 2012). These authors are critical of the crudity of the indicators used to measure such disadvantage and warn that epigenetic 'stigma', likely associated with poverty, could justify sociopolitical interventions targeting certain populations' choices in education, lifestyle and nutrition (Katz, 2014). These authors do not mention more up-to-date research, which deserves critical sociological attention and may open research avenues for interdisciplinary collaboration.

Notably, the 'epigenetic clock' model aims to provide a general measure of everyday 'wear and tear'. Sociologists of health and disease have begun to use biomarkers to 'link social processes to the physiological workings of our bodies and minds' (Timmermans, 2008). One can question whether epigenetic clocks will complement or even replace the use of disputed biomarkers such as cortisol levels in sociological studies. Next, the notion of 'epigenetic programming' to disease during earlylife, which was particularly strong in the initial formulation of the DOHaD hypothesis and conveyed a deterministic view of health outcomes, has been losing ground to the notion of epigenetic 'plasticity' throughout life (Hanson \& Gluckman, 2016). This may open up interdisciplinary research avenues on 
To cite this article Louvel, S. (2020). What's in a name? The three genealogies of the social in social epigenetics. Social Science Information. https://doi.org/10.1177/0539018419897001

social factors promoting resilience to the biological weathering effects of adversity at individual, neighborhood and societal levels (McEwen \& McEwen, 2017; Eastwood et al., 2019). Lastly, social epigenetics define adverse social contexts in more detailed and diverse ways than just maternal care and nutrition, from economic hardship to racial segregation and neighborhood crime. Social scientists can enrich these definitions through ethnographic observation of what makes life difficult for families, neighborhoods or populations and how such groups cope with 'structurally unequal social, political, or environmental ecologies' (Geronimus, 2013). They may also contribute to developing the ecological approaches that are lacking in post-genomic conceptualizations of the environment (Shostak \& Moinester, 2015). Through these new research directions, social epigenetics might come closer to becoming an inter-discipline between the natural and social sciences, as it ought to be.

\section{Funding}

This work was supported by the French National Research Agency in the framework of the 'Investissements d'avenir' program (ANR-15-IDEX-02).

\section{References}

Andrés A (2009) Measuring Academic Research: How to Undertake a Bibliometric Study. Amsterdam: Elsevier.

Barker DJ (1990) The fetal and infant origins of adult disease. BMJ: British Medical Journal 301(6761): 1111.

Ben-Shlomo Y, Cooper R, Kuh D (2016) The last two decades of life course epidemiology, and its relevance for research on ageing. International Journal of Epidemiology 45(4): 973-988.

Borghol N, Suderman M, McArdle W, Racine A, Hallet, M, Pembrey M, Hertzman C, Power C, Szyf M (2012) Associations with early-life socio-economic position in adult DNA methylation. International journal of epidemiolog, 41(1): 62-74.

Brody GH, Yu T, Beach SRH (2016) Resilience to adversity and the early origins of disease. Development and psychopathology 28(4pt2): 1347-1365.

Brown A, Fiori LM, Turecki G (2019) Bridging basic and clinical research in early life adversity, DNA Methylation, and major depressive disorder. Frontiers in genetics 10.

Buchen L (2010) Neuroscience: In their nurture. Nature News 467(7312): 146-148.

Burt CH, Simons RL (2014) Pulling back the curtain on heritability studies: Biosocial criminology in the postgenomic era. Criminology 52(2): 223-262.

Callard F, Fitzgerald D (2015) Rethinking Interdisciplinarity Across the Social Sciences and Neurosciences. London: Palgrave Macmillan.

Cao-Lei L, Massart R, Suderman MJ, Machnes Z, Elgbeili G, Laplante DP, Szyf M, King S (2014) DNA methylation signatures triggered by prenatal maternal stress exposure to a natural disaster: Project Ice Storm. PloS one 9(9): pp. e107653.

Champagne FA (2012) Interplay between social experiences and the genome: Epigenetic consequences for behavior. In: Sokolowski MB, Goodwin SF (eds) Gene-Environment Interplay Advances in Genetics. Amsterdam: Academic Press, 33-57.

Chiapperino L, Panese F (2018) Gendered imaginaries: Situating knowledge of epigenetic programming of health. Sociology of health \& illness 40(7): 1233-1249.

Chiapperino L, Testa G (2016) The epigenomic self in personalized medicine: Between responsibility and empowerment. The Sociological Review Monographs 64(1): 203-220.

Chung E, Cromby J, Papadopoulos D, Tufarelli C (2016) Social epigenetics: A science of social science? The Sociological Review 64(S1): 168-185.

Claeys A, Vialatte J-S (2016) Les enjeux et les perspectives de l'épigénétique dans le domaine de la santé. Report, L'Office parlementaire d'évaluation des choix scientifiques et technologiques, Paris, France.

Eastwood JG, Garg P, Tyler I, De Souza DE (2019) A critical realist translational social epidemiology protocol for concretising and contextualising a 'theory of neighbourhood context, stress, depression, and the Developmental Origins of Health and Disease (DOHaD)', Sydney Australia. International journal of integrated care 19(3). 
To cite this article Louvel, S. (2020). What's in a name? The three genealogies of the social in social epigenetics. Social Science Information. https://doi.org/10.1177/0539018419897001

Essex MJ, Thomas Boyce W, Hertzman C, Lam LL, Armstrong JM, Neumann SMA, Kobor MS (2013) Epigenetic vestiges of early developmental adversity: Childhood stress exposure and DNA methylation in adolescence. Child development 84(1): 58-75.

Fiorito G, Polidoro S, Dugué P-A, Kivimaki M, Ponzi E, Matullo G, Guarrera S, Assumma MB, Georgiadis P, Kyrtopoulos SA (2017) Social adversity and epigenetic aging: A multi-cohort study on socioeconomic differences in peripheral blood DNA methylation. Scientific reports 7(1): 16266.

Geronimus AT (2013) Deep integration: Letting the epigenome out of the bottle without losing sight of the structural origins of population health. American journal of public health 103(S1): S56-S63.

Golden SA, Covington HE III, Berton O, Russo SJ (2011) A standardized protocol for repeated social defeat stress in mice. Nature protocols 6(8): 1183-1191.

Hanson M (2015) The birth and future health of DOHaD. Journal of developmental origins of health and disease 6(5): 434-437.

Hanson MA, Gluckman PD (2015) Developmental origins of health and disease-global public health implications. Best practice \& Research Clinical Obstetrics \& Gynaecology 29(1): 24-31.

Hanson MA, Gluckman PD (2016) Commentary: Developing the future: life course epidemiology, DOHaD and evolutionary medicine. International Journal of Epidemiology 45(4): 993-996.

Hanson MA, Müller R (2017) Epigenetic inheritance and the responsibility for health in society. The Lancet Diabetes \& Endocrinology 5(1): 11-12.

Heijmans BT, Tobi EW, Stein AD, Putter H, Blauw GJ, Susser ES, Slagboom PE, Lumey LH (2008) Persistent epigenetic differences associated with prenatal exposure to famine in humans. Proceedings of the National Academy of Sciences 105(44): 17046-17049.

Jasienska G (2009) Low birth weight of contemporary African Americans: An intergenerational effect of slavery? American Journal of Human Biology: The Official Journal of the Human Biology Association 21(1): 16-24.

Katz M (2014) The biological inferiority of the undeserving poor. Social Work \& Society 12(2). Available at: http://www.socwork.net/sws/article/view/359/709.

Kenney M, Müller R (2017) Of rats and women: Narratives of motherhood in environmental epigenetics. BioSocieties 12(1): 23-46.

Kogan SM, Cho J, Beach SRH, Smith AK, Nishitani S (2018) Oxytocin receptor gene methylation and substance use problems among young African American men. Drug and Alcohol Dependence 192: 309-315.

Kuzawa CW, Sweet E (2009) Epigenetics and the embodiment of race: Developmental origins of US racial disparities in cardiovascular health. American Journal of Human Biology 21(1): 2-15.

Labonte B, Yerko V, Gross J, Mechawar N, Meaney MJ, Szyf M, Turecki G (2012) Differential glucocorticoid receptor exon $1 \mathrm{~B}, 1 \mathrm{C}$, and $1 \mathrm{H}$ expression and methylation in suicide completers with a history of childhood abuse. Biological psychiatry 72(1): 41-48.

Landecker H (2011) Food as exposure: Nutritional epigenetics and the new metabolism. BioSocieties 6(2): 167-194.

Landecker H (2016) The social as signal in the body of chromatin. The Sociological Review Monographs 64(1): 79-99.

Landecker H, Panofsky A (2013) From social structure to gene regulation, and back: A critical introduction to environmental epigenetics for sociology. Annual Review of Sociology 39: 333-357.

Lappé M, Landecker H (2015) How the genome got a life span. New genetics and society 34(2): 152176.

Lei M-K, Beach SRH, Simons RL, Philibert RA (2015) Neighborhood crime and depressive symptoms among African American women: Genetic moderation and epigenetic mediation of effects. Social science \& medicine 146: 120-128.

Lloyd S, Raikhel E (2018) Epigenetics and the suicidal brain: Reconsidering context in an emergent style of reasoning. In: Meloni M, Cromby J, Fitzgerald D, Lloyd S (eds) The Palgrave Handbook of Biology and Society. London: Plagrave Macmillan, 491-515.

Lock M (2015) Comprehending the body in the era of the epigenome. Current Anthropology 56(2): 151-177.

Lock M, Palsson G (2016) Can Science Resolve the Nature/Nurture Debate? Hoboken: John Wiley \& Sons. 
To cite this article Louvel, S. (2020). What's in a name? The three genealogies of the social in social epigenetics. Social Science Information. https://doi.org/10.1177/0539018419897001

Loi M, Del Savio L, Stupka E (2013) Social epigenetics and equality of opportunity. Public Health Ethics 6(2): 142-153.

Lupien SJ, McEwen BS, Gunnar MR, Heim C (2009) Effects of stress throughout the lifespan on the brain, behaviour and cognition. Nature reviews neuroscience 10(6): 434.

López-Jaramillo P, Silva SY, Rodríguez-Salamanca N, Duran A, Mosquera W, Castillo V (2008) Are nutrition-induced epigenetic changes the link between socioeconomic pathology and cardiovascular diseases? American Journal of Therapeutics 15(4): 362-372.

Macvarish J, Lee E, Lowe P (2014) The 'first three years' movement and the infant brain: A review of critiques. Sociology Compass 8(6): 792-804.

Mansfield B (2012) Race and the new epigenetic biopolitics of environmental health. BioSocieties 7(4): 352-372.

McEwen CA, McEwen BS (2017) Social structure, adversity, toxic stress, and intergenerational poverty: An early childhood model. Annual Review of Sociology 43: 445-472.

McGowan PO, Sasaki A, D'Alessio AC, Dymov S, Labonté B, Szyf M, Turecki G, Meaney MJ (2009) Epigenetic regulation of the glucocorticoid receptor in human brain associates with childhood abuse. Nature neuroscience 12(3): 342-348.

McGuinness D, McGlynn LM, Johnson PCD, MacIntyre A, Batty GD, Burns H, Cavanagh J, Deans KA, Ford I, McConnachie A (2012) Socio-economic status is associated with epigenetic differences in the pSoBid cohort. International journal of epidemiology 41(1): 151-160.

Meloni M (2013) Biology without biologism: Social theory in a postgenomic age. Sociology 48(4): 731-746.

Meloni M (2017) Race in an epigenetic time: Thinking biology in the plural. The British Journal of Sociology 68(3): 389-409.

Meloni M, Cromby J, Fitzgerald D, Lloyd S (2018) The Palgrave Handbook of Biology and Society. London: Plagrave Macmillan.

Meloni M, Müller R (2018) Transgenerational epigenetic inheritance and social responsibility: Perspectives from the social sciences. Environmental epigenetics 4(2): dvy019.

Miller GE (2010) The seductive allure of behavioral epigenetics. Science 329(5987): 24-27.

Miller GE, Chen E, Fok AK, Walker H, Lim A, Nicholls EF, Cole S, Kobor MS (2009) Low early-life social class leaves a biological residue manifested by decreased glucocorticoid and increased proinflammatory signaling. Proceedings of the National Academy of Sciences 106(34): 14716-14721.

Miller GE, Yu T, Chen E, Brody GH (2015) Self-control forecasts better psychosocial outcomes but faster epigenetic aging in low-SES youth. Proceedings of the National Academy of Sciences 112(33): 10325-10330.

Niewöhner J (2011) Epigenetics: Embedded bodies and the molecularisation of biography and milieu. Biosocieties 6(3): 279-298.

Palma-Gudiel H, Córdova-Palomera A, Leza JC, Fananás L (2015) Glucocorticoid receptor gene (NR3C1) methylation processes as mediators of early adversity in stress-related disorders causality: A critical review. Neuroscience \& Biobehavioral Reviews 55: 520-535.

Park M, Kobor MS (2015) The potential of social epigenetics for child health policy. Canadian Public Policy 41(S2): S89-S96.

Provenzi L, Giorda R, Beri S, Montirosso R (2016) SLC6A4 methylation as an epigenetic marker of life adversity exposures in humans: A systematic review of literature. Neuroscience \& Biobehavioral Reviews 71: 7-20.

Raimbault B, Cointet J-P, Joly PB (2016) Mapping the emergence of synthetic biology. PloS one 11(9): e0161522.

Richardson SS (2015) Maternal bodies in the postgenomic order. In: Richardson SS, Stevens H (eds) Postgenomics Perspective on Biology after the Genome. Durham, NC: Duke University Press, 210231.

Richardson SS, Stevens H (2015) Postgenomics Perspective on Biology after the Genome. Durham, NC: Duke University Press.

Richmond RC, Joubert BR (2017) Contrasting the effects of intra-uterine smoking and one-carbon micronutrient exposures on offspring DNA methylation. Epigenomics 9(3): 351-367.

Roth TL, Lubin FD, Funk AJ, Sweatt JD (2009) Lasting epigenetic influence of early-life adversity on the BDNF gene. Biological psychiatry 65(9): 760-769. 
To cite this article Louvel, S. (2020). What's in a name? The three genealogies of the social in social epigenetics. Social Science Information. https://doi.org/10.1177/0539018419897001

Rothstein MA, Cai Y, Marchant GE (2009) The ghost in our genes: Legal and ethical implications of epigenetics. Health Matrix Cleveland 19(1): 1-62.

Saldaña-Tejeda A (2018) Mitochondrial mothers of a fat nation: Race, gender and epigenetics in obesity research on Mexican mestizos. BioSocieties 13(2): 434-452.

Saulnier KM, Dupras C (2017) Race in the postgenomic era: Social epigenetics calling for interdisciplinary ethical safeguards. The American Journal of Bioethics 17(9): 58-60.

Senellart P, Blondel VD (2008) Automatic discovery of similar words. In: Berry MW (ed.) Survey of Text Mining II. New York: Springer, 25-43.

Sharp GC, Lawlor DA, Richardson SS (2018) It's the mother!: How assumptions about the causal primacy of maternal effects influence research on the developmental origins of health and disease. Social Science \& Medicine 213: 20-27.

Shostak S (2007) Translating at work: Genetically modified mouse models and molecularization in the environmental health sciences. Science, Technology, \& Human Values 32(3): 315-338.

Shostak S, Moinester M (2015) The missing piece of the puzzle? Measuring the environment in the postgenomic moment. In: Richardson S, Stevens H (eds) Postgenomics. Perspectives on biology after the genome. Durham, NC: Duke University Press, 192-209.

Simons RL, Lei MK. Beach SRH, Philibert RA, Cutrona CE, Gibbons FX, Barr A (2016) Economic hardship and biological weathering: The epigenetics of aging in a US sample of black women. Social Science \& Medicine 150: 192-200.

Soh S-E, Chong Y-S, Kwek K, Saw S-M, Meaney MJ, Gluckman PD, Holbrook JD, Godfrey KM, Group GS (2014) Insights from the growing up in Singapore towards healthy outcomes (GUSTO) cohort study. Annals of Nutrition and Metabolism 64(3/4): 218-225.

Stringhini S, Polidoro S, Sacerdote C. Kelly RS, Van Veldhoven K, Agnoli C, Grioni S, Tumino R, Giurdanella MC, Panico S (2015) Life-course socioeconomic status and DNA methylation of genes regulating inflammation. International journal of epidemiology 44(4): 1320-1330.

Strong J, Combs-Orme T (2018) Understanding human behavior: What social workers need to know about animal research. Journal of Human Behavior in the Social Environment 28(7): 817-828.

Timmermans S, Haas S (2008) Towards a sociology of disease. Sociology of Health \& Illness 30(5): 659-676.

Tsankova NM, Berton O, Renthal W, Kumar A, Neve RL, Nestler EJ (2006) Sustained hippocampal chromatin regulation in a mouse model of depression and antidepressant action. Nature neuroscience 9(4): 519-525.

Turecki G, Meaney MJ (2016) Effects of the social environment and stress on glucocorticoid receptor gene methylation: A systematic review. Biological Psychiatry 79(2): 87-96.

Vineis P, Chadeau-Hyam M, Gmuender H, Gulliver J, Herceg Z, Kleinjans J, Kogevinas M, Kyrtopoulos S, Nieuwenhuijsen M, Phillips DH (2017) The exposome in practice: Design of the EXPOsOMICS project. International Journal of Hygiene and Environmental Health 220(2): 142-151. Warin M, Moore V, Zivkovic T, Davies M (2011) Telescoping the origins of obesity to women's bodies: How gender inequalities are being squeezed out of Barker's hypothesis. Annals of Human Biology 38(4): 453-460.

Waterland RA, Jirtle RL (2003) Transposable elements: Targets for early nutritional effects on epigenetic gene regulation. Molecular and cellular biology 23(15): 5293-5300.

Waterland RA, Jirtle RL (2004) Early nutrition, epigenetic changes at transposons and imprinted genes, and enhanced susceptibility to adult chronic diseases. Nutrition 20(1): 63-68.

Weaver ICG, Cervoni N, Champagne FA, D'Alessio AC, Sharma S, Seckl JR, Dymov S, Szyf M, Meaney MJ (2004) Epigenetic programming by maternal behavior. Nature neuroscience 7(8): 847854.

Weisz G, Cambrosio A, Cointet J-P (2017) Mapping global health: A network analysis of a heterogeneous publication domain. BioSocieties 12(4): 520-542.

White LO, Klein AM, Kirschbaum C, Kurz-Adam M, Uhr M, Müller-Myhsok B, Hoffmann K, Sierau S, Michel A, Stalder T (2015) Analyzing pathways from childhood maltreatment to internalizing symptoms and disorders in children and adolescents (AMIS): A study protocol. BMC Psychiatry 15(1): 126.

White SJ, Wastell DG (2016) Epigenetics prematurely born(e): Social work and the malleable gene. British Journal of Social Work 47(8): 2256-2272. 
To cite this article Louvel, S. (2020). What's in a name? The three genealogies of the social in social epigenetics. Social Science Information. https://doi.org/10.1177/0539018419897001

Zannas AS, Arloth J, Carrillo-Roa T, Iurato S, Röh S, Ressler KJ, Nemeroff CB, Smith AK, Bradley B, Heim C (2015) Lifetime stress accelerates epigenetic aging in an urban, African American cohort: Relevance of glucocorticoid signaling. Genome Biology 16(1): 266.

Zannas AS, West AE (2014) Epigenetics and the regulation of stress vulnerability and resilience. Neuroscience 264: 157-170.

\section{Annex}

Table 3. Steps for bibliometric analysis

\section{STEP 1 - Corpus building from the Web of Science (WOS) database}

I used a combination of search terms describing research in epigenetics - validated by biologists - and of search terms explicitly including 'social' in the title, abstract or keyword.

\section{Search terms}

Title, Abstract, Keyword=((((epigenetic* OR "DNA methyl*” OR (methylation AND (gene OR CpG)) OR "DNA hydroxymethyl*" OR *hydroxymethylcytosine* OR "histone marks" OR "histone retention" OR "histone modification" OR "histone *acetyl*” OR "histone *methyl*" OR "histone *sumoyl*” OR "histone phosphoryl*” OR "histone ribosyl*” OR "histone ubiquitin*” OR "small non coding RNA" OR "small noncoding RNA" OR "endogenous small interfering RNA" OR microRNA OR piRNA OR miRNA OR "piwi-interacting RNA" OR lincRNA OR lncRNA OR "long non coding RNA” OR “long noncoding RNA" OR "hypomethylation” OR "hypermethylation”))) AND (Social OR "socio economic" OR "socioeconomic” OR "psychosocial” OR "psycho-social”) NOT ("eusocial” OR “social insect” OR "social insects” OR “apis mellifica” OR autism))

LANGUAGE: (English)

Indexes=SCI-EXPANDED, SSCI, A\&HCI, CPCI-S, CPCI-SSH, ESCI

Timespan $=2000-2018$

For steps 2 and 3 (descriptive statistics, network analysis and graphical representations) I used the online platform CorText Manager: https://managerv2.cortext.net/

\section{STEP 2 - Descriptive statistics}

Number of publications and its evolution over time, 20 main authors, number of newcomers (authors entering the corpus), top 20 journals and areas of publication, top 20 journals and areas of citation.

STEP 3 - Analysis of co-citation networks: I selected the top 200 most frequently cited references. The structure of the network has been detected through a clustering algorithm (Senellart \& Blondel, 2008). The optimal modularity obtained by the Louvain algorithm for this co-citation network (which measures the density of edges inside communities to edges outside communities) is 0.69. I characterized each sub-corpus by its most specific keywords, cited authors, authors and WOS categories.

I used the software Gephi for the graphical representations. The co-citation networks are represented as follows: node color depends on their cluster assignment; node size scale is proportional to the node's degree (i.e. the number of connections to the node).

Table 4. Summary of the five epistemic backgrounds of social epigenetics

\begin{tabular}{|c|c|c|c|c|}
\hline \multirow[b]{2}{*}{ Sub-corpus } & \multicolumn{4}{|c|}{ Bibliometric indicators: most specific... } \\
\hline & Keywords & Cited authors & Authors & WOS categories \\
\hline $\begin{array}{l}\text { Social } \\
\text { defeat } \\
\text { (animals) }\end{array}$ & $\begin{array}{lr}\text { depression, } & \text { social } \\
\text { defeat, } & \text { nucleus } \\
\text { accumbens, } & \text { animal }\end{array}$ & $\begin{array}{l}\text { Covington, H.E. } \\
\text { Krishnan, V. } \\
\text { Berton, O. }\end{array}$ & $\begin{array}{l}\text { Nestler, E.J. } \\
\text { Neve, R.L. } \\
\text { Dias, C. }\end{array}$ & $\begin{array}{l}\text { Neuroscience } \\
\text { Psychiatry } \\
\text { Pharmacology \& pharmacy }\end{array}$ \\
\hline
\end{tabular}


To cite this article Louvel, S. (2020). What's in a name? The three genealogies of the social in social epigenetics. Social Science Information. https://doi.org/10.1177/0539018419897001

\begin{tabular}{|c|c|c|c|c|}
\hline & $\begin{array}{l}\text { model, hippocampus, } \\
\text { histone acetylation }\end{array}$ & $\begin{array}{l}\text { Tsankova, N.M. } \\
\text { Renthal, W. }\end{array}$ & $\begin{array}{l}\text { Covington, H.E. } \\
\text { Maze, I. } \\
\text { Golden, S.A. }\end{array}$ & \\
\hline $\begin{array}{l}\text { Early-life } \\
\text { adversity } \\
\text { (animals) }\end{array}$ & $\begin{array}{l}\text { maternal care, } \\
\text { maternal behavior, } \\
\text { maternal development, } \\
\text { social behavior }\end{array}$ & $\begin{array}{l}\text { Champagne, F.A. } \\
\text { Liu, D. } \\
\text { Razin, A. } \\
\text { Levine, S. } \\
\text { Francis, D. }\end{array}$ & $\begin{array}{l}\text { Guidotti, A. } \\
\text { Nicoletti, F. } \\
\text { Matrisciano, F. } \\
\text { Auger, A.P. } \\
\text { Grayson, D.R. } \\
\text { Gluckman, P.D. }\end{array}$ & $\begin{array}{l}\text { Behavioral sciences } \\
\text { Zoology } \\
\text { Biological psychology }\end{array}$ \\
\hline $\begin{array}{l}\text { Trauma } \\
\text { (humans) }\end{array}$ & $\begin{array}{l}\text { Post-Traumatic Stress } \\
\text { Disorder, trauma, HPA } \\
\text { axis, cortisol, } \\
\text { glucocorticoid } \\
\text { receptor }\end{array}$ & $\begin{array}{l}\text { Perroud, N. } \\
\text { Labonte, B. } \\
\text { Tyrka, A.R. } \\
\text { Provencal, N. } \\
\text { Klengel, T. }\end{array}$ & $\begin{array}{l}\text { Smith, A.K. } \\
\text { Kirschbaum, C. } \\
\text { Fananas, L. } \\
\text { Palma-Gudiel, H. } \\
\text { Deckert, J. } \\
\text { Szyf, M. }\end{array}$ & $\begin{array}{l}\text { Psychiatry } \\
\text { Educational psychology } \\
\text { General and internal medicine }\end{array}$ \\
\hline $\begin{array}{l}\text { Nutrition } \\
\text { (humans) }\end{array}$ & $\begin{array}{l}\text { obesity, genetics, race, } \\
\text { nutrition, epigenetics, } \\
\text { epigenetic inheritance }\end{array}$ & $\begin{array}{l}\text { Waterland, R.A. } \\
\text { Gluckman, P.D. } \\
\text { Barker, D.I.P. } \\
\text { Heijmans, B. } \\
\text { Landecker, H. }\end{array}$ & $\begin{array}{l}\text { Christensen, K. } \\
\text { Godfrey, K.M. } \\
\text { Gluckman, P.D. } \\
\text { Lerner, R.M. } \\
\text { Hanson, M.A. } \\
\text { López-Jaramillo, P. } \\
\text { Soh, S.E. }\end{array}$ & $\begin{array}{l}\text { Public, environmental \& occupational } \\
\text { health } \\
\text { Endocrinology \& metabolism }\end{array}$ \\
\hline $\begin{array}{l}\text { Life course } \\
\text { (humans) }\end{array}$ & $\begin{array}{lr}\text { childhood } & \text { adversity, } \\
\text { health } & \text { disparities, } \\
\text { lifecourse } & \text { SEP, } \\
\text { biomarkers, prevention }\end{array}$ & $\begin{array}{l}\text { Miller, G.E. } \\
\text { Boyce, W.T. } \\
\text { Cole, S.W. } \\
\text { Ellis, B.J. } \\
\text { McEwen, B.S. }\end{array}$ & $\begin{array}{l}\text { Horvath, S. } \\
\text { Brody, G.H. } \\
\text { Stringhini, S. } \\
\text { Lei, M.K. } \\
\text { Philibert, R.A. } \\
\text { Beach, S.R.H. }\end{array}$ & $\begin{array}{l}\text { Psychology (general and } \\
\text { developmental) } \\
\text { Public, environmental \& occupational } \\
\text { health } \\
\text { Rehabilitation }\end{array}$ \\
\hline
\end{tabular}

